\title{
Discovery of variant infectious salmon anaemia virus (ISAV) of European genotype in British Columbia, Canada
}

\author{
Molly JT Kibenge ${ }^{1}$, Tokinori Iwamoto ${ }^{1,5}$, Yingwei Wang ${ }^{2}$, Alexandra Morton ${ }^{3}$, Richard Routledge ${ }^{4}$
} and Frederick SB Kibenge ${ }^{1 *}$

\begin{abstract}
Background: Infectious salmon anaemia (ISA) virus (ISAV) belongs to the genus Isavirus, family Orthomyxoviridae. ISAV occurs in two basic genotypes, North American and European. The European genotype is more widespread and shows greater genetic variation and greater virulence variation than the North American genotype. To date, all of the ISAV isolates from the clinical disease, ISA, have had deletions in the highly polymorphic region (HPR) on ISAV segment 6 (ISAV-HPRA) relative to ISAV-HPRO, named numerically from ISAV-HPR1 to over ISAV-HPR30. ISA outbreaks have only been reported in farmed Atlantic salmon, although ISAV has been detected by RT-PCR in wild fish. It is recognized that asymptomatically ISAV-infected fish exist. There is no universally accepted ISAV RT-qPCR TaqMan ${ }^{\circledR}$ assay. Most diagnostic laboratories use the primer-probe set targeting a 104 bp-fragment on ISAV segment 8. Some laboratories and researchers have found a primer-probe set targeting ISAV segment 7 to be more sensitive. Other researchers have published different ISAV segment 8 primer-probe sets that are highly sensitive.

Methods: In this study, we tested 1,106 fish tissue samples collected from (i) market-bought farmed salmonids and (ii) wild salmon from throughout British Columbia (BC), Canada, for ISAV using real time RT-qPCR targeting segment 8 and/or conventional RT-PCR with segment 8 primers and segment 6 HPR primers, and by virus isolation attempts using Salmon head kidney (SHK-1 and ASK-2) cell line monolayers. The sequences from the conventional PCR products were compared by multiple alignment and phylogenetic analyses.
\end{abstract}

Results: Seventy-nine samples were "non-negative" with at least one of these tests in one or more replicates. The ISAV segment 6 HPR sequences from the PCR products matched ISAV variants, HPR5 on 29 samples, one sample had both HPR5 and HPR7b and one matched HPRO. All sequences were of European genotype. In addition, alignment of sequences of the conventional PCR product segment 8 showed they had a single nucleotide mutation in the region of the probe sequence and a 9-nucleotide overlap with the reverse primer sequence of the real time RT-qPCR assay. None of the classical ISAV segment 8 sequences in the GenBank have this mutation in the probe-binding site of the assay, suggesting the presence of a novel ISAV variant in BC. A phylogenetic tree of these sequences showed that some ISAV sequences diverted early from the classical European genotype sequences, while others have evolved separately. All virus isolation attempts on the samples were negative, and thus the samples were considered "negative" in terms of the threshold trigger set for Canadian federal regulatory action; i.e., successful virus isolation in cell culture.

\footnotetext{
* Correspondence: kibenge@upei.ca

${ }^{1}$ Department of Pathology and Microbiology, Atlantic Veterinary College,

University of Prince Edward Island, 550 University Ave., Charlottetown, P.E.I.

C1A 4P3, Canada

Full list of author information is available at the end of the article
} 
(Continued from previous page)

Conclusions: This is the first published report of the detection of ISAV sequences in fish from British Columbia, Canada. The sequences detected, both of ISAV-HPR $\Delta$ and ISAV-HPRO are of European genotype. These sequences are different from the classical ISAV segment 8 sequences, and this difference suggests the presence of a new ISAV variant of European genotype in BC. Our results further suggest that ISAV-HPR $\Delta$ strains can be present without clinical disease in farmed fish and without being detected by virus isolation using fish cell lines.

Keywords: Infectious salmon anaemia virus, ISAV, ISAV variant, European genotype

\section{Background}

Infectious salmon anaemia virus (ISAV) is an economically important pathogen of marine-farmed Atlantic salmon (Salmo salar L.). The disease infectious salmon anaemia (ISA) is arguably the most feared viral disease of the marine farmed salmon industry because it has continued to cause the Atlantic salmon farming industry severe economic losses in an increasing number of countries for the past 30 years. ISAV is the only species of the genus Isavirus, and one of the seven genera of the family Orthomyxoviridae that includes the influenza viruses [1-3]. A complete sequence of PB1 gene of a putative koi carp orthomyxovirus was obtained from koi carp in California with $43 \%$ amino acid sequence identity with ISAV [4], and there is also an independent reference to an orthomyxovirus from koi carp [5], and to unknown viruses with morphology consistent with members of family Orthomyxoviridae isolated from baitfish in Wisconsin, USA [6]. The taxonomic status of these findings is not known. ISAV occurs in two basic genotypes, North American and European [7, 8]. The European genotype is more widespread [9] and shows greater genetic variation $[10,11]$ and greater virulence variation [12-14] than the North American genotype. ISA outbreaks have only been reported in farmed Atlantic salmon, although ISAV has been detected by RT-PCR in wild fish (Table 1 ). It is recognized that asymptomatically ISAV-infected fish exist $[15,16]$. Since 2012, only Norway, Canada and Chile have reported ISA outbreaks. The ISA outbreaks reported in Canada have occurred in the Atlantic Ocean in New Brunswick, Nova Scotia, and Newfoundland and Labrador [17].

ISAV has a segmented genome with eight singlestranded RNA segments of negative polarity [1]. The Orthomyxoviridae family is known to exhibit high mutation rates, and ISAV occurs in at least 30 recognized HPR variants $[9,18]$. When viruses mutate, 'drift variants' arise

Table 1 Timeline (chronological history) of the detection of ISAV in wild fish related to first-time outbreaks of ISA in farmed Atlantic salmon

\begin{tabular}{|c|c|c|c|}
\hline Year of sample \&Test used & Country (location) & $\begin{array}{l}\text { Wild fish species with ISAV } \\
\text { (reference) }\end{array}$ & $\begin{array}{l}\text { First-time outbreaks of ISA in } \\
\text { farmed Atlantic salmon in country (reference) }\end{array}$ \\
\hline $\begin{array}{l}\text { 1998-1999, Virus Isolation \& } \\
\text { RT-PCR }\end{array}$ & UK (Scotland) & $\begin{array}{l}\text { Sea trout, Brown trout, Atlantic } \\
\text { salmon [61] }\end{array}$ & Scotland, UK in 1998 [47] \\
\hline 2000, RT-PCR & Canada (New Brunswick) & Salmonids [62] & New Brunswick, Canada in 1996 [63] \\
\hline 2000, RT-PCR & UK (Scotland) & Atlantic salmon [49] & \\
\hline 2000, RT-PCR & UK (Scotland) & $\begin{array}{l}\text { Sea trout, Brown trout, } \\
\text { Atlantic salmon [64] }\end{array}$ & \\
\hline 2001, RT-PCR & West Greenland fishery & Atlantic salmon [65] & \\
\hline 2001, RT-PCR & USA (Maine) & $\begin{array}{l}\text { Atlantic salmon } \\
\text { (P. Barbash, cited by [66]) }\end{array}$ & Maine, USA in 2001 [67] \\
\hline $\begin{array}{l}\text { 2000-2002, Virus Isolation \& } \\
\text { RT-PCR }\end{array}$ & USA (Maine) & Pollock*, Atlantic cod** [66] & \\
\hline 1998; 2001-2003, RT-PCR & Norway (western Norway) & $\begin{array}{l}\text { Salmonids (wild trout, Atlantic } \\
\text { salmon) [31] }\end{array}$ & Norway in 1984 [68] \\
\hline 1995-2002, Antibody ELISA & USA (Maine \& Massachusetts) & Atlantic salmon [69] & \\
\hline 2010, RT-PCR & Denmark & Atlantic salmon ${ }^{\S}[70]$ & \\
\hline \multirow[t]{2}{*}{ 2010, RT-PCR } & $\begin{array}{l}\text { Chile (an estuary in southern } \\
\text { Chile) }\end{array}$ & $\begin{array}{l}\text { free-living Salmo salar } \\
\text { (escapees) [15] }\end{array}$ & Chile in 2007 [71] \\
\hline & Faroe Islands, Denmark & & Faroe Islands, Denmark in 2000 [72] \\
\hline
\end{tabular}

*Pollock taken from inside a marine cage with ISA-disease salmon was weak RT-PCR positive;

${ }^{* *}$ Atlantic cod taken from a well boat holding salmon from a marine cage with clinically diseased fish was CPE positive on SHK cell culture.

${ }^{5}$ Danish salmon produced for restocking purposes. 
that can escape detection by real-time RT-qPCR tests due to mismatches in the primer-probe binding sites [19]. When a mutation occurs in the precise region that a given primer or probe was designed to anneal, test reliability can be significantly decreased [20] producing inconsistent positive and false-negative readings between replicates [21]. There is no scientific standard for interpretation of high, or inconsistent threshold cycle $\left(C_{\mathrm{t}}\right)$ values, and so these kinds of results are interchangeably reported as "negative," "suspicious" or "positive" $[22,23]$. For the purposes of this work, we simply designated our results as negative or non-negative.

In Canada, a federally reportable fish disease such as ISA must be confirmed at the Fisheries and Oceans (DFO) Canada National Reference Laboratory [24] through successful virus isolation in cell culture [25]. However, ISAV-HPR $\triangle$ strains of low virulence and the non-pathogenic ISAV-HPR0 strains grow poorly or not at all in currently available fish cell lines [15, 26-29]. Gagné and Ritchie [30] report an increasing number of ISAV positive results by RT-PCR in Canada that cannot be confirmed by other diagnostic tests. It is also recognized in Norway that ISAV may be present even when attempts at virus isolation are negative as ISAV has never been isolated from a wild salmon despite positive RT-PCR results (Table 1) [31].

While virus isolation is considered the "gold standard" for virus identification [32], it can produce "false negative results" [20]. Virus isolation requires tissue heavily infected with intact virus [33], which is unlikely to be found in wild salmon which are culled by predators that target weakened fish [34]. As well, intact, infective ISAV may not reliably occur in healthy salmon that have been harvested for several days, such as fish found in markets. Molecular tests, however, have the capacity to detect low levels of virus fragments [35] making them ideally suited for the types of samples available to this study.

There is no universally accepted ISAV RT-qPCR TaqMan $^{\circ}$ assay. Most diagnostic laboratories use the Snow et al. [36] primer-probe set targeting a $104 \mathrm{bp}-$ fragment on ISAV segment $8[37,38]$. Some laboratories and researchers have found the Plarre et al. [31] primerprobe set targeting ISAV segment 7 to be more sensitive. Other researchers have published different ISAV segment 8 primer-probe sets that are highly sensitive [13], but are not included in the OIE Manual [38]. There is also a long standing conventional RT-PCR protocol targeting ISAV segment 8 using a primer set initially developed by Devold et al. [39], which is less sensitive than real time RT-qPCR. This yields a PCR product of $221 \mathrm{bp}$, which includes the first $94 \mathrm{bp}$ of the $104 \mathrm{bp}-$ PCR amplicon of the Snow et al. [36] RT-qPCR TaqMan ${ }^{\circ}$ assay, with the reverse primer sequences of both assays overlapping in 9 nucleotides. While preliminary results from this study were interpreted as controversial [40,
41], they are consistent with the nature of both the tests and the samples, i.e., wild fish and fish from markets. The findings in the present study are supported by the many unpublished ISAV RT-PCR positive results in farmed and wild salmon in British Columbia, which exist as unpublished federal laboratory exhibits released by the Cohen Commission into the Decline of the Sockeye Salmon of the Fraser River [42]. Here we present more complete test results demonstrating that the ISAV sequences detected in British Columbia (BC) fish, both ISAV-HPR $\triangle$ and ISAV-HPR0, are of European genotype, with a mismatch in segment 8 that contributes to the inconsistent results of the RT-qPCR TaqMan assay, and represents a new ISAV variant that appears to occur in BC in absence of high losses to the salmon farming industry. It would add to the knowledge of ISAV to test fresh moribund farmed salmon using the methods we describe here.

\section{Results and Discussion}

Sample RNA quality was based on real-time RT-PCR for ELF-1 $a$ as internal control for all samples

The ELF- $1 \alpha$ controls showed a considerable variation between samples (within and between species). Fig. 1 highlights the systematic difference in the threshold cycle $\left(C_{\mathrm{t}}\right)$ values for the market-sampled vs. fieldsampled fish. It also highlights two outliers in each of the two groups. The log sheets for the two anomalously large values in the field-sampled group indicate potential delays in sample processing under suboptimal conditions. The anomalously low values in the marketsampled group came from a single shopping event. This

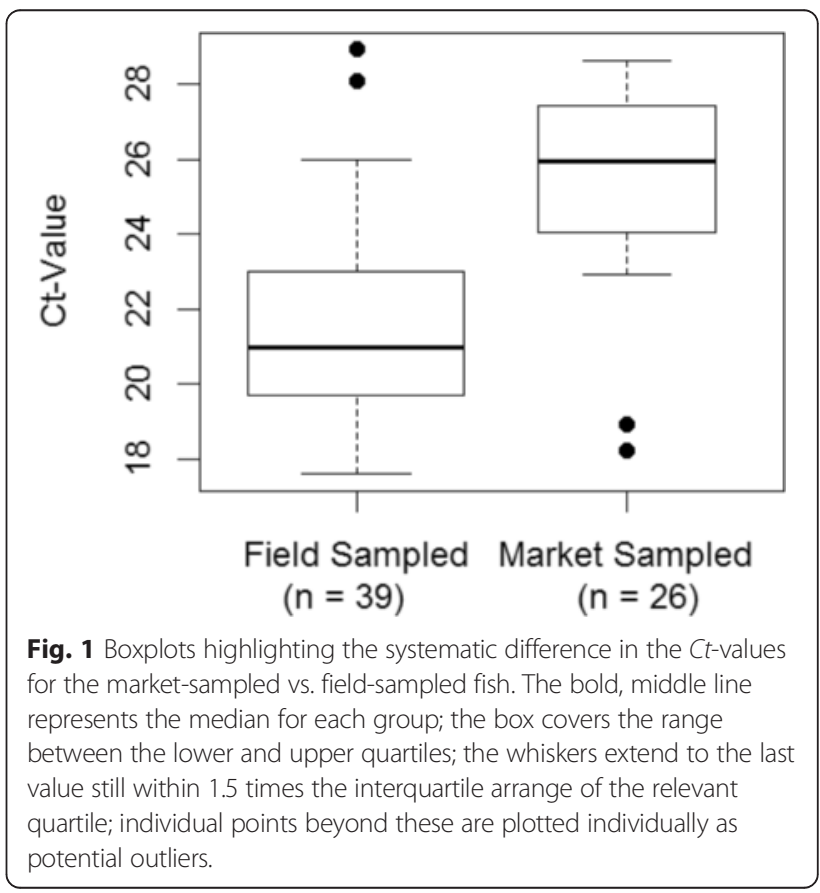


in turn suggests that these fish were perhaps atypically fresh. Both these sets of outliers point to the potential for differences between sampling events to account for a substantial portion of the variability in these $C_{t}$ values. A formal analysis of a mixed-effects model for these values using the R package, 'Ime4' [43], provided the following estimates: (i) that the mean $C_{\mathrm{t}}$ values for the market-sampled group was 2.94 units higher than the mean for the field-sampled group, and (ii) that the standard deviation of the within-samplingevent means was 2.57 , and that the residual deviation was only 1.47 . Although the data set was too small to provide precise estimates of these parameters, it appears that most of the variability in the $C_{\mathrm{t}}$ values can be accounted for by variation in the sample quality much of it unavoidably associated with the necessity to rely on (i) market purchases of farmed fish and (ii) logistics of sampling remote regions of British Columbia.

\section{Fewer than $2.0 \%$ of British Columbia fish tested were "non-negative" in the real time RT-qPCR TaqMan ${ }^{\circledR}$ assay for ISAV}

In the present study, we used the Snow et al. [36] primer-probe set targeting segment 8 with a cut-off $C_{\mathrm{t}}$ value established as the mean $C_{\mathrm{t}}$ value in the highest virus dilution for which all 30 replicates were positive (Additional file 1: Table S1). Thus for the purposes of this study, samples were considered "non-negative" when the fluorescence signal increased above the $C_{\mathrm{t}}$, and if the $C_{\mathrm{t}}$ value was $\leq 34.20$. Samples with $C_{\mathrm{t}}>34.2$ to $\leq$ 39.9 were considered weak "non-negative" and $>40$, suspicious as $C_{\mathrm{t}}$ of the last five cycles has higher uncertainity. Where the $C_{\mathrm{t}}$ value was zero, the result was deemed to be negative.

A total of 1,106 tissue samples were collected from market-sourced farmed salmon (397) and wild fish (708) obtained from (i) saltwater commercial fisheries, (ii) freshwater and saltwater sport fisheries, (iii) research sampling of juvenile salmon in seawater, and (iv) spawning adult salmon in freshwater habitat throughout British Columbia, Canada. As well, a sea louse (Lepeophtheirus salmonis) removed from a juvenile sockeye salmon was sampled. All samples were tested for ISAV using published real time RT-qPCR and/or conventional RT-PCR. The test results are detailed in Additional file 2: Table S2 and summarized in Table 2. Out of the total of 1,106 tissue samples, 20 $(1.81 \%)$ tested had a $C_{\mathrm{t}}$ value (Table 2 ). Of these, only one sample (Fish \# VR5, a spawning chum salmon in freshwater) was also positive in conventional RT-PCR with segment 8 and segment 6 HPR primers. One sample (Fish \# TT48, an Atlantic salmon from a market) was also positive in conventional RT-PCR with segment 8 , and two samples (Fish\# SK20 and TT51, both Atlantic salmon from markets) were also positive in conventional RT-PCR with segment $6 \mathrm{HPR}$ primers. The percentage of samples with a $C_{\mathrm{t}}$ value was more than two-fold greater in farmed fish tissues $(2.77 \%)$ compared to wild fish tissues $(1.3 \%)$. There were 56/65 fish that produced positive conventional RT-PCR results with no RT-PCR $C_{\mathrm{t}}$ values. All virus isolation attempts on these samples using ASK-2 and SHK-1 cell lines were negative. From a Canadian regulatory perspective, diagnostic confirmation requires virus isolation on permissive fish cell lines and virus identification [25] hence a sample with a $C_{\mathrm{t}}$ value or positive conventional RT-PCR in this study was designated as "non-negative".

\section{ISAV sequences detected in British Columbia fish have a mismatch in segment 8 compared to classical ISAV and represent a new ISAV variant of European genotype}

Whereas all fish tissue samples were screened by the real time RT-qPCR TaqMan ${ }^{\circ}$ assay for ISAV, only a portion of these samples was additionally tested by conventional RT-PCR for segment 8 or segment 6 HPR. Table 2 lists all non-negative test results by species and by farmed vs. wild status. This study did not attempt a direct comparison of the 3 different RT-PCR assays. Such an effort would require standardizing sample quality, which would require direct access to salmon in the farms.

To determine the genetic relationship between the ISAV sequences in this study and ISAV strains worldwide, we compared the segment 8 sequences using multiple alignment and phylogenetic analysis. All the 50 sequences from this study aligned well in a $221 \mathrm{bp}-$ long fragment with 47 selected classical ISAV segment 8 sequences of different ISAV isolates in GenBank (GenBank Database) (Fig. 2). This alignment revealed a consistent single nucleotide mutation (5'-CAT CGT CGC TGC AGA TC-3') in the 3' region of the probe sequence (5'-CAT CGT CGC TGC AGT TC-3') [36]. This mutation in the BC samples would contribute to the apparent failure of the real time RT-qPCR TaqMan assay for ISAV in the 49 samples, positive in segment 8 , but with no $C_{\mathrm{t}}$ value in the real time RT-qPCR TaqMan ISAV assay. None of the classical ISAV segment 8 sequences in the GenBank database have this mutation. While a single nucleotide variation is a minor mutation, its placement in a region that an ISAV probe sequence seeks to anneal in a standard OIE ISAV test, makes this a significant mutation that warrants recognition as a new variant. Improvements aimed at better detection of this variant are currently being developed. Recognition of, and testing for, this variant are essential prerequisites for determining how widespread it is.

The alignment of amino acid sequences in a 118 bplong fragment of the same ISAV sequences in Fig. 2 without the primer sequences is shown in Fig. 3. The polypeptide aligned well. The number of mutations shown in Fig. 3 is slightly less than the number of 
Table 2 Number of samples for each species that (i) tested non-negative for infectious salmon anaemia virus (ISAV) by RT-qPCR ${ }^{1}$ and that produced sequences by conventional PCR for (ii) segment 6 and (iii) segment 8

\begin{tabular}{|c|c|c|c|c|c|c|c|c|c|}
\hline \multicolumn{2}{|c|}{ Fish species } & \multicolumn{4}{|c|}{ Farmed fish } & \multicolumn{4}{|c|}{ Wild fish } \\
\hline $\begin{array}{l}\text { Common } \\
\text { name }\end{array}$ & Scientific name & $\mathrm{n}$ & $\begin{array}{l}\text { RT- } \\
\text { qPCR }\end{array}$ & $\begin{array}{l}\text { Conventional PCR seg. } \\
8 \text { sequence }\end{array}$ & $\begin{array}{l}\text { Conventional PCR } \\
\text { seg. } 6 \text { sequence }\end{array}$ & $\mathrm{n}$ & $\begin{array}{l}\text { RT- } \\
\text { qPCR }\end{array}$ & $\begin{array}{l}\text { Conventional PCR seg. } \\
8 \text { sequence }\end{array}$ & $\begin{array}{l}\text { Conventional PCR seg } \\
6 \text { sequence }\end{array}$ \\
\hline $\begin{array}{l}\text { Atlantic } \\
\text { salmon }\end{array}$ & Salmo salar & 334 & 9 & 18 & $13^{2}$ & & & & \\
\hline $\begin{array}{l}\text { Chinook } \\
\text { salmon }\end{array}$ & $\begin{array}{l}\text { Oncorhynchus } \\
\text { tshawytscha }\end{array}$ & 13 & 0 & 0 & 0 & 102 & 2 & 2 & 0 \\
\hline $\begin{array}{l}\text { Coho } \\
\text { salmon }\end{array}$ & $\begin{array}{l}\text { Oncorhynchus } \\
\text { kisutch }\end{array}$ & 4 & 0 & 0 & 0 & 68 & 1 & 6 & 1 \\
\hline $\begin{array}{l}\text { Sockeye } \\
\text { salmon }\end{array}$ & $\begin{array}{l}\text { Oncorhynchus } \\
\text { nerka }\end{array}$ & & & & & 256 & 3 & 7 & 2 \\
\hline Kokanee & $\begin{array}{l}\text { Oncorhynchus } \\
\text { nerka }\end{array}$ & & & & & 1 & 1 & 1 & $\mathrm{Na}$ \\
\hline $\begin{array}{l}\text { Pink } \\
\text { salmon }\end{array}$ & $\begin{array}{l}\text { Oncorhynchus } \\
\text { gorbuscha }\end{array}$ & & & & & 118 & 0 & 2 & 0 \\
\hline $\begin{array}{l}\text { Chum } \\
\text { salmon }\end{array}$ & $\begin{array}{l}\text { Oncorhynchus } \\
\text { keta }\end{array}$ & & & & & 68 & 1 & 1 & 1 \\
\hline $\begin{array}{l}\text { Steelhead } \\
\text { trout }\end{array}$ & $\begin{array}{l}\text { Oncorhynchus } \\
\text { mykiss }\end{array}$ & 46 & 2 & 3 & 0 & 21 & 0 & $\mathrm{Na}$ & $\mathrm{Na}$ \\
\hline $\begin{array}{l}\text { Cutthroat } \\
\text { trout }\end{array}$ & $\begin{array}{l}\text { Oncorhynchus } \\
\text { clarkii }\end{array}$ & & & & & 18 & 0 & $8^{3}$ & 13 \\
\hline $\begin{array}{l}\text { Chum } \\
\text { mackerel }\end{array}$ & Scomber japonicus & & & & & 13 & 0 & 1 & 0 \\
\hline $\begin{array}{l}\text { Pacific } \\
\text { herring }\end{array}$ & Clupea pallasi & & & & & 44 & 0 & 1 & 0 \\
\hline Sea louse & $\begin{array}{l}\text { Lepeophtheirus } \\
\text { salmonis }\end{array}$ & & & & & 1 & 1 & 0 & 0 \\
\hline Total & & 397 & 11 & 21 & 13 & 709 & 9 & 29 & 17 \\
\hline
\end{tabular}

${ }^{1}$ All fish tissue samples were screened by the real time RT-qPCR TaqMan ${ }^{\oplus}$ assay for ISAV. However, only some of the samples were also tested in conventional RTPCR for segment 6 HPR or segment 8 . Therefore, the numbers do not reflect a direct comparison of the 3 different RT-PCR assays. Na denotes Not applicable.

${ }^{2} 2$ others with a PCR product but not sequenced.

${ }^{3} 5$ others with a PCR product but not sequenced.

mutations in Fig. 2. This is because of the redundancy nature of the genetic code. For example, the mutation from AAAGCCC to AAGGCCC in VT02142014-120 is not shown in Fig. 3; this is because both AAA and AAG are translated to $\mathrm{K}$. The single nucleotide mutation in the probe sequence of Snow et al. [36] resulted in a single amino acid change from $\mathrm{V}$ to $\mathrm{D}$ and would therefore produce a functional full-length viral protein.

Phylogenetic analysis was used to further determine the genetic relationship between the newly discovered BC ISAV variant in the present study and the classical ISAV strains worldwide. Fig. 4 shows the phylogenetic tree generated with these sequences with satisfactory bootstrap support (bootstrapping values more than $70 \%$ are marked). In addition to showing the relationship of the ISAV sequences from this study (all "VT" sequences), this tree also supports the well-established major division between North American genotype and European genotype ISAV. All the ISAV sequences detected in this study are of the European genotype. While these BC sequences tend to be similar to each other, their differences with other European sequences are very small. The apparent wide diversity of the $\mathrm{BC}$ sequences in the tree reflects the nature of the sampling, and the fact that there was no single-source-selected amplification as occurs with the classical ISAV isolates from disease outbreaks. Moreover, the branching in the tree also indicates that some (VT02142012-120, VT08092012-449, and VT08092012-402) diverted early from most of the classical European genotype sequences, while others (VT06062013-60, VT08092012-465, VT05012012-308, and VT06202012-391) have evolved separately. The data support the observation that ISAV can exist in a region for a period of years in absence of outbreaks and in a state that may not be detectable by methods designed to diagnose virulent outbreaks in moribund farmed fish.

ISAV sequences detected in British Columbia fish include both ISAV-HPRA and ISAV-HPRO and are of European genotype

The detection of ISAV-HPR0 in British Columbia fish (Fish\# SK20) was designated a suspect result by the 


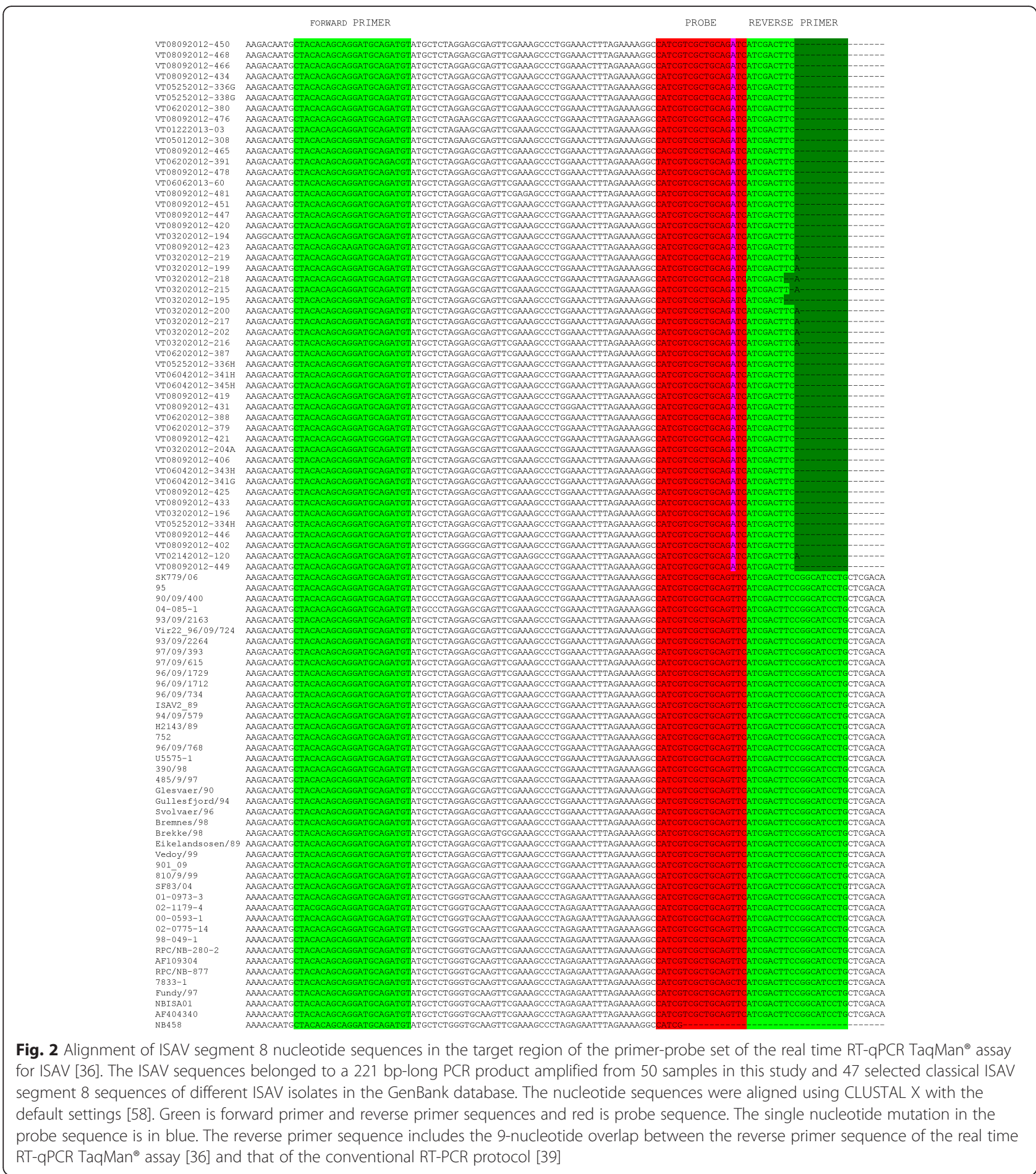

Canadian Food Inspection Agency (CFIA), because of the inability for follow up by the federal authorities. With the widespread occurrence of ISAV-HPR0 variants in many parts of the world and its potential as a precursor to the virulent strains of ISAV [13], it is essential that RT-PCR positive results based on segment 8 primers be followed up with conventional
RT-PCR using segment 6 primers targeting the HPR. Sequencing of the PCR product is also essential in order to determine the ISAV HPR type present (ISAV-HPRA or ISAV-HPR0 or both) [9]. ISAVHPRO has only been reported in apparently healthy fish and has never been associated with clinical or pathological diagnosis of ISA disease [44]. 


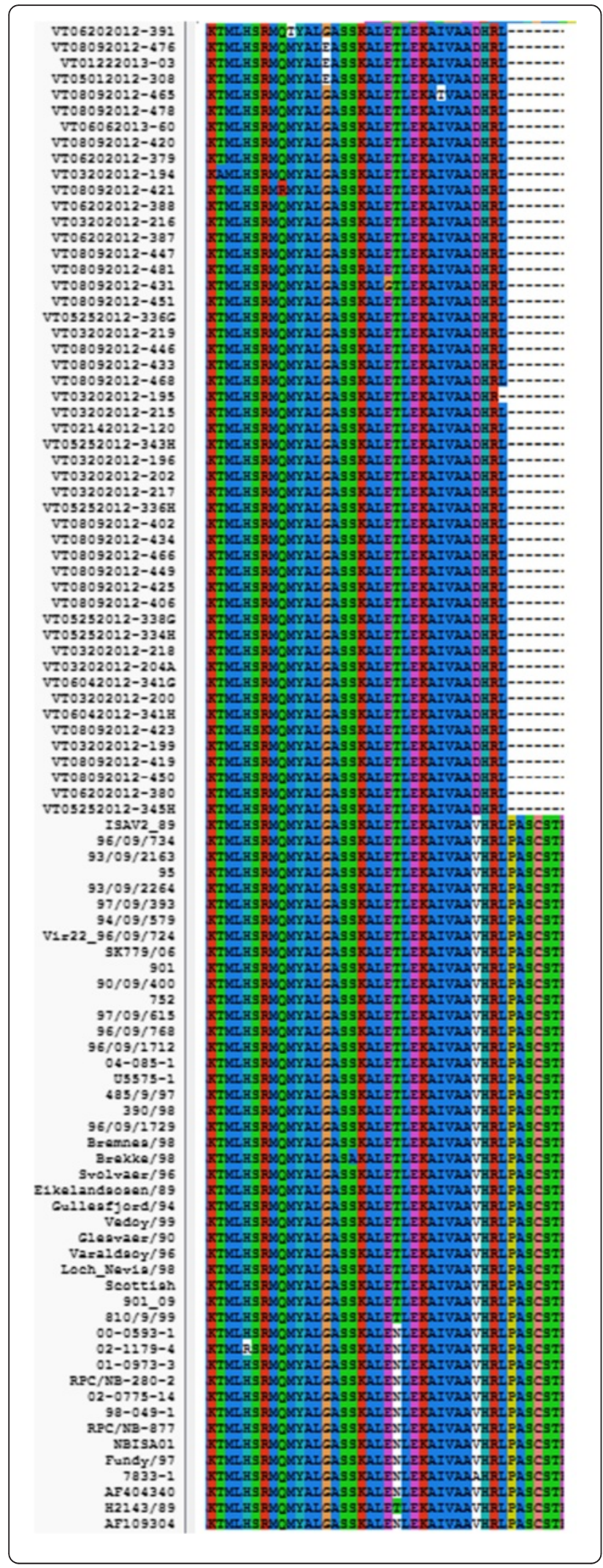

Fig. 3 Alignment of ISAV segment 8 amino acid sequences in the target region of the primer-probe set of the real time RT-qPCR TaqMan ${ }^{\oplus}$ assay for ISAV [36]. The ISAV sequences are those in Fig. 2. The amino acid sequences in the region between the two primers (Forward Primer and Reverse Primer) were aligned using CLUSTAL X with the default settings [58]. The single nucleotide mutation in the probe sequence resulted in a single amino acid change from $V$ to $D$

Of the fish tested in conventional RT-PCR for segment $6 \mathrm{HPR}$, sequences of the PCR product were obtained from 13 farmed fish samples (13 Atlantic salmon) and 17 from wild fish samples (1 coho, 2 Sockeye, 1 Chum and 13 Cutthroat) (Table 2). In contrast to conventional RT-PCR for segment 8, where 49 samples positive in segment 8 had no $C_{\mathrm{t}}$ value in the real time RT-qPCR TaqMan $^{\bullet}$ assay for ISAV, only 3 samples (Fish\# SS132, MQ06, and P113, Additional file 2: Table S2) were positive in conventional RT-PCR for segment 6 , with no $C_{t}$ value. These samples were also negative by conventional RT-PCR for segment 8.

The sequences of ISAV segment 6 obtained from the PCR products matched ISAV-HPR5 on 29 samples, one had both ISAV-HPR5 and ISAV-HPR7b and one sample matched ISAV-HPRO (Additional file 2: Table S2). All were of European genotype. ISAV-HPRA strains of HPR 5 and HPR7b types have been associated with ISA outbreaks in Norway [45, 46], Scotland [47] and Chile $[9,48]$. Thus our data indicate that ISAV-HPR $\Delta$ strains can be present without clinical disease in farmed fish and without being detected by virus isolation, which is in agreement with other reports $[15,16]$.

To determine the genetic relationship between the segment $6 \mathrm{HPR}$ sequences detected in BC and worldwide, we compared the HPR sequences using multiple alignment and phylogenetic analysis. A total of 316 sequences aligned well and the phylogenetic tree was generated depicting the overall relationship among all ISAV isolates for which segment 6 sequence is available (data not shown). Virulent ISAV isolates have a deletion in segment 6 HPR sequence [44]. Of the 316 segment 6 HPR sequences, we only identified 101 sequences that were long enough to display this deletion. We aligned these 101 sequences to show the deletion. No existing alignment software packages can align nucleotide sequences in this delicate and complex area, thus the alignment has been manually adjusted. When we prepared a figure to show these sequences and the deletion, we found it is hard to show so many sequences in a figure so that some of the sequences that behave the same in this deletion area were removed. Fig. 5 shows a portion of the alignment containing the deletion. In this figure, 71 sequences were included, representing the 101 sequences. The first five sequences of the alignment, including VT12212012-1068, are complete, i.e., they have 


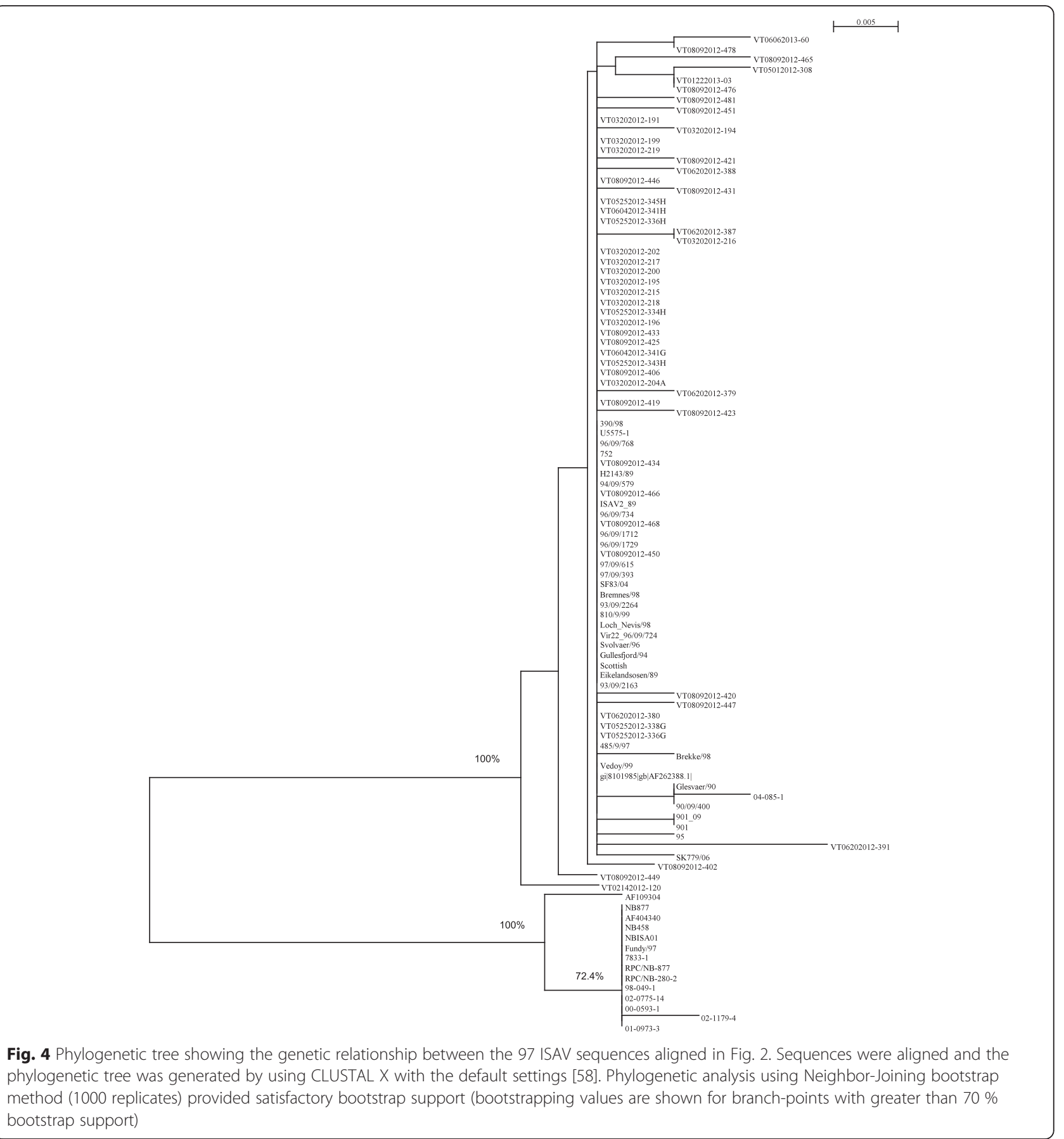

no deletion and belong to ISAV-HPR0 [49]. The rest of the sequences have a deletion and belong to ISAVHPR $\Delta[11,44]$.

The alignment of amino acid sequences of the ISAV segment 6 HPR sequences in Fig. 5 without the primer sequences is shown in Fig. 6. Both figures show extensive deletions in the HPR. Existing software cannot produce high-quality alignments in areas with deletions. Thus this alignment was manually adjusted to reveal the deletion event. The deletions in HPR probably occur through homologous recombination (copy-choice recombination, presumably because of strand-switching by the viral RNA polymerase [50] during negative RNA strand synthesis from one nucleic acid template of one virus to another. Fig. 6 confirms the three ISAV HPR types found in the BC samples: ISAV-HPR0 (VT12212012-1068), ISAV-HPR7b (VT03282012-222-C and VT02142012-90), and ISAV-HPR5 (VT05252012$337 \mathrm{G}$ and 5 other samples) and also reveals the relationship 


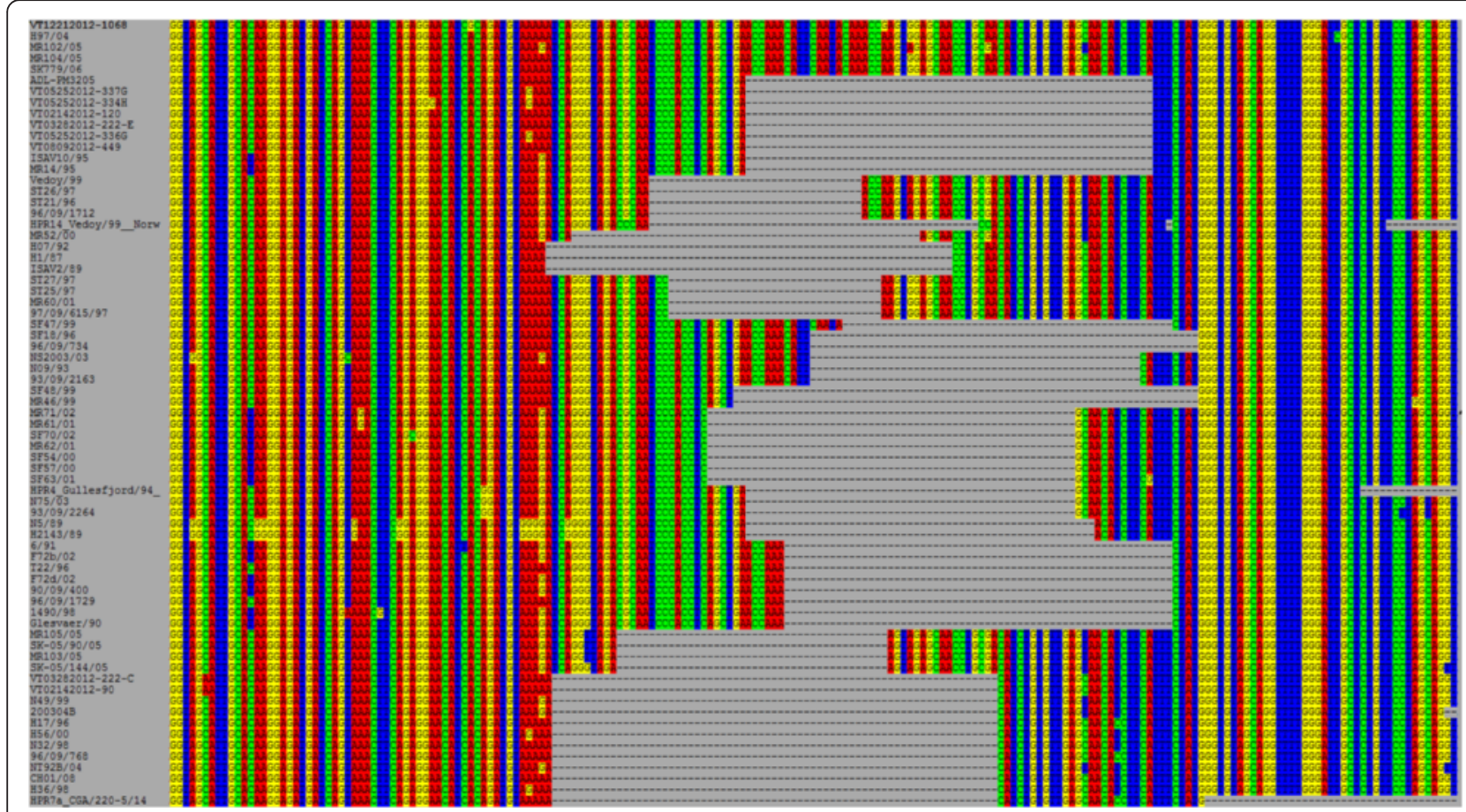

Fig. 5 Alignment of ISAV segment 6 HPR nucleotide sequences containing the deletion. The alignment was adjusted manually as all known alignment software packages cannot align nucleotide sequences in such a delicate and complex area. Among 101 sequences analyzed, 39 of them are British Columbia isolates (ID starts with VT); the deletions of these 39 sequences are in three patterns. The first pattern is VT122120121068; the second pattern is VT03282012-222-C and VT02142012-90; the third pattern has 36 isolates and this pattern can be shown in VT05252012-337G. To save space in the figure, we used 6 sequences to represent the 36 sequences in this pattern

between these HPR types and ISAV HPR types in other countries.

Fig. 7 shows the phylogenetic tree generated with the sequences in Fig. 4 with satisfactory bootstrap support (bootstrapping values more than $70 \%$ are marked); where NBISA01/98 is used as an outgroup. This tree contains only the isolates from Fig. 5. It was not created to reflect the whole evolutionary history of ISAV segment 6 , but to help with the analysis of the HPR deletion. Comparing Figs. 5, 6 and 7, we can find some consistency, i.e. isolates that show the same deletion pattern tend to be closer inside the tree. Although such consistency only exists for a few groups, the combination of these two approaches may reveal more insights on ISAV's evolutionary history.

\section{Conclusions}

To our knowledge the present work constitutes the first published report of the detection of ISAV sequences in fish from British Columbia, Canada. The sequences detected, both of ISAV-HPRA and ISAV-HPRO are of European genotype. The virus in these samples has a mismatch in segment 8 that can account for failure of the real time RT-qPCR TaqMan ${ }^{\circ}$ assay for ISAV recommended in the OIE Aquatic Manual. Furthermore, these sequences are different from the classical ISAV segment
8 sequences, and this difference suggests the presence of a new ISAV variant of European genotype in BC. Our results further suggest that ISAV-HPRA strains can be present without clinical disease in farmed fish and without being detected by virus isolation using fish cell lines. Recent reports on ISAV surveillance in Washington, USA [41], and in British Columbia [17] report no ISAV detection. However, neither of these studies report on samples from the known target host of ISAV, farmed Atlantic salmon, and it is unreported whether weak RTPCR positives similar to ours were found, and interpreted as "negative". More research on the source of this variant ISAV sequence is critically important for assessing the risks to both farmed and wild salmon in the region, its origin and to better understand ISAV evolution.

\section{Methods \\ Sampling}

Wild fish were collected from freshwater spawning grounds, fresh and saltwater sport fisheries, saltwater commercial fisheries, and saltwater scientific fisheries. Wild fish samples included all species of Pacific salmon (Oncorhynchus sp.), Atlantic salmon (Salmo salar), steelhead (Oncorhynchus mykiss), cutthroat trout (Oncorhynchus clarkii), kokanee (Oncorhynchus nerka), Pacific chub mackerel (Scomber japonicus) and Pacific herring (Clupea 


\begin{tabular}{|c|c|}
\hline $3 \times 779 / 06$ & 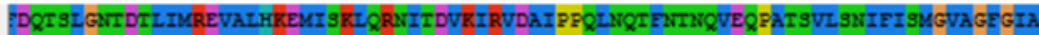 \\
\hline $\operatorname{MR} 102 / 05$ & 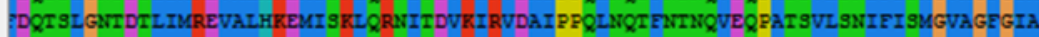 \\
\hline B97/04 & 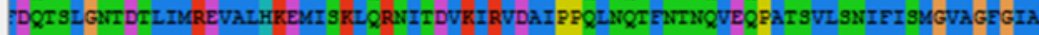 \\
\hline MR104/05 & 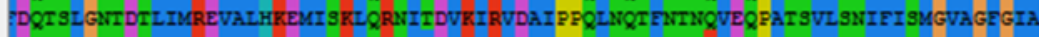 \\
\hline VT12212012-1068 & 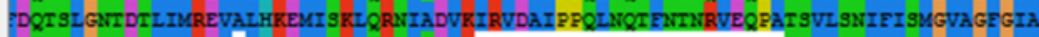 \\
\hline VT02142012-90 & 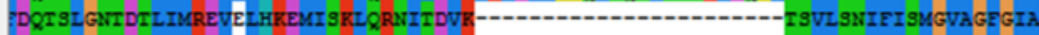 \\
\hline VT03282012-222-c & 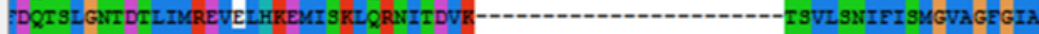 \\
\hline $\mathrm{CH} 01 / 0 \mathrm{~s}$ & PDTSLGITDTLTMREVALHKEMISKLQRNITDVR- \\
\hline H36/98 & PQTISLGIDTLIMREVALHKEMISKLQRUITDVE- \\
\hline H56/00 & DQTSLGITDTLIMREVALHKEMISKLQRUITDVE- \\
\hline $2 \pi 92 B / 04$ & DQTSLGITDTLTMREVALHKEMISKLQRUITDVR- \\
\hline $2 \pi 32 / 98$ & DQTSLGITDTLIMREVALHKEMISKLQRUITDVR---. \\
\hline $\mathrm{H} 17 / 96$ & PDTISLGITDTLIMREVALHKEMISKLQRUITDVR---- \\
\hline $2749 / 99$ & PQRISLGITDILTMREVALHKEMISKLQRUITDVR---- \\
\hline $96 / 09 / 768$ & PDQTSLGITDILTMREVALHKEMISRLQRUITDVR----. \\
\hline $200304 \mathrm{~B}$ & PQTSLGITDTLIMREVALHKEMISKL QRUITDVR--. \\
\hline HPR7a_CGM/220-5/14 & PDLISLGIIDTLIMREVALHKEMISRLQRRITDVR----- \\
\hline ISAV2/89 & PDQTSLGIIDTLIMREVALHKEMISKLQRRIITDVR----- \\
\hline $\mathrm{H1} / 87$ & PDQISIGIIDTLIMREVALHKEMISKLQRNITDVR----. \\
\hline H07/92 & PDQTSLGITDTLIMREVALHKEMISKLQRRIITDVR------. \\
\hline MR52/00 & PQRTSLGITDILIMREVALHKEMISKLERUITDVKIR---- \\
\hline HPR14_Vedoy/99 & PDQISLGIIDTLIMREVALHKEMISKLQRUITDVRIRVD--- \\
\hline Vedoy/ 99 & 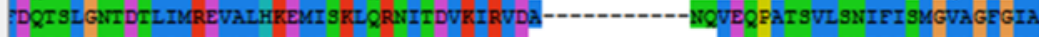 \\
\hline MR103/05 & DQRISLGITDTLIMREVALHKEMISKLQRUITDVRIRLE------ \\
\hline MR105/05 & 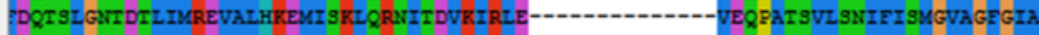 \\
\hline $3 R-05 / 90 / 05$ & PDQISLGIIDTLIMREVALHKEMI SKLQRUIITVVIRLE-----. \\
\hline $3 \mathrm{R}-05 / 144 / 05$ & 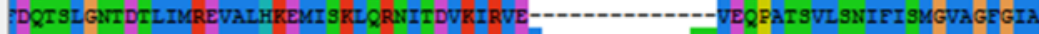 \\
\hline $3 T 21 / 96$ & PDQISLGITDTLIMREVALHKEMI SKLQRUITDVKIRVDA----- \\
\hline $3526 / 97$ & PDQISIGITDTLIMREVALHKEMI SKLQRUITDVKIRVDA----- \\
\hline $96 / 09 / 1712$ & PDQTSLGITDTLIMREVALHKEMISKLQRUITDVRIRVDA----.. \\
\hline $3 T 25 / 97$ & PDQISIGIIDTLIMREVALHKEMI SRLQRUITDVRIRVDAI---. \\
\hline $3527 / 97$ & DQTISLGITDTLIMREVALHKEMISRLQRUITDVRIRVDAI---.. \\
\hline $97 / 09 / 615 / 97$ & PDQISIGITDTLIMREVALHKEMI SRLQRUITDVRIRVDAI---. \\
\hline MR60/01 & PDQTSLGITDTLIMREVALHKEMI SKLQRUITDVRIRVDAI---- \\
\hline $3554 / 00$ & PDQTSLGITDTLIMREVALHKEMISKLQRUITDVRIRVDAIPPR- \\
\hline $3570 / 02$ & DQTISIGIIDTLIMREVALHREMISRLQRUIITDVRIRVDAIPPR- \\
\hline $3557 / 00$ & PDQISLGIIDTLIMREVALHREMISKLQRUITDVRIRVDAIPPR- \\
\hline MRE2/01 & PDQISLGITDILIMREVALHKEMISKLQRRIITDVKIRVDAIPPR-- \\
\hline MR71/02 & DQTSIGIIDTLIMREVALHKEMISRLQRIITDVKIRVDAIPPR--- \\
\hline MR61/01 & DQTSIGITDILIMREVALHKEMISRLQRRIITDVKIRVDAIPPR-- \\
\hline SE $63 / 01$ & PDQTSLGIIDILIMREVALHKEMI SKL QRUITDVRIRVDAI PPR--- \\
\hline HPR4_Gullesfjord/94 & DQTSLGIIDTLIMREVALHKEMISRLQRUITDVRIRVDAIPFQI-- \\
\hline 2875/03 & PDQISIGIIDTLIMREVALHKEMISKLQRUITDVRIRVDAIPPQI \\
\hline $93 / 09 / 2264$ & PQISLGITDTLIMREVALHKEMI SKLQRRIITDVKIRVDAIPFQI- \\
\hline 255/89 & PDT SLGITDALVMGEVALHGEMISELRRUITDVGIGVDAIPFQLN \\
\hline $\mathrm{H} 2143 / 89$ & PDQISLGITDALVMGEVALHGEMISELRRWITDVGIGVDAIPFQL: \\
\hline VT05252012-337G & PDQISLGITDTHIMREVALHKEMISKLQRUIT DVEIRVDAIPFQH- \\
\hline VT05252012-336G & DQRTSLGITDTHIMREVALHKEMI SKLQRUITDVEIRVDAIPFQI \\
\hline VT05252012-334H & PDQTSLGITDTHIMREVALHKEMI SKLQRDITDVEIRVDAIPFQI \\
\hline VT02142012-120 & PDQISIGITDTHIMREVALHKEMI SKLQRUITDVKIRVDAIPFQI \\
\hline VT03282012-222-E & PQIGLGITDTHIUREVALHKEMISKLQRUITDVRIRVDAIPFQI \\
\hline VT08092012-449 & PDQTSLGITDTLQVREVALHKEMI SKLQRUITDVRIRVDAIPFQI-- \\
\hline ADL-FM3205 & 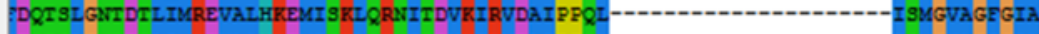 \\
\hline MR14/95 & DQRI SLGIIDTLIMREVALHKEMI SKLQRUITDVRIRVDAIPPQL---- \\
\hline ISAV10/95 & PDISIGGIDTLIMREVALHKEMI SKLQRUITDVRIRVDAIPFQI---- \\
\hline $93 / 09 / 2163$ & 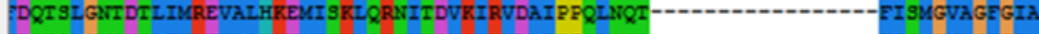 \\
\hline $2732003 / 03$ & 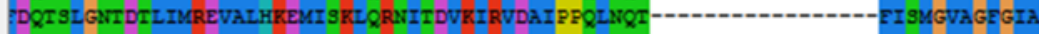 \\
\hline $209 / 93$ & 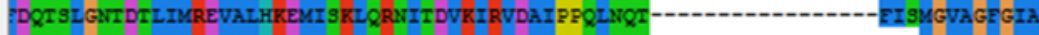 \\
\hline Glesvaer/90 & 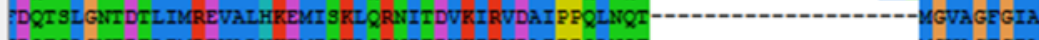 \\
\hline $90 / 09 / 400$ & 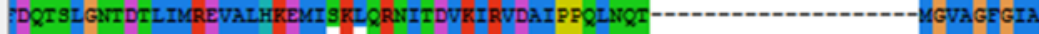 \\
\hline $1490 / 98$ & DQTSLGITDILIMREVALHKEMIRRRQRIITDVKIRVDAIPFQLNQT- \\
\hline $6 / 91$ & PDQISLGIIDTLIMREVALHKEMISKLQRRITDVRIRVDAIPFQLMQT- \\
\hline $572 \mathrm{~b} / 02$ & 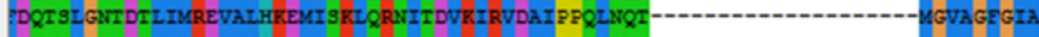 \\
\hline $\mathrm{F} 7 \mathrm{~d} / 02$ & 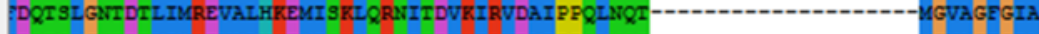 \\
\hline $\mathrm{T22} / 96$ & 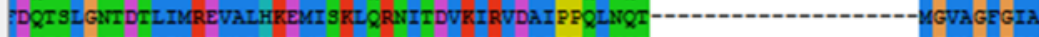 \\
\hline $96 / 09 / 1729$ & 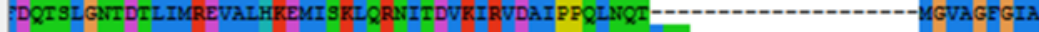 \\
\hline $3547 / 99$ & 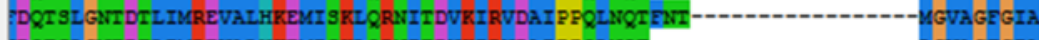 \\
\hline $3518 / 96$ & 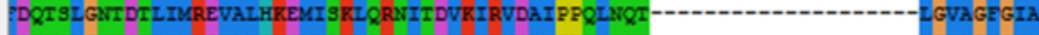 \\
\hline $96 / 09 / 734$ & 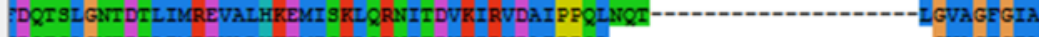 \\
\hline $3548 / 99$ & 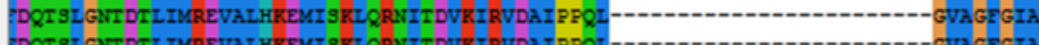 \\
\hline MR46/99 & 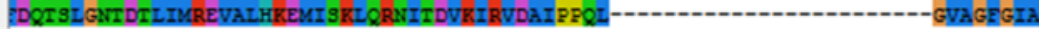 \\
\hline nd on next page.) & \\
\hline
\end{tabular}


(See figure on previous page.)

Fig. 6 Alignment of ISAV segment 6 HPR amino acid sequences containing the deletion. The alignment was adjusted manually as all known alignment software packages cannot align amino acid sequences in such a delicate and complex area in Fig. 5. The alignment confirms the three ISAV HPR patterns in Fig. 5: The first pattern VT12212012-1068 belongs to ISAV-HPRO; the second pattern VT03282012-222-C and VT02142012-90 belongs to ISAV-HPR7b; the third pattern with 36 isolates and shown in VT05252012-337G belongs to ISAV-HPR5. Similarly to Fig. 5, only 6 of the 36 sequences in the third pattern are included in Fig. 6

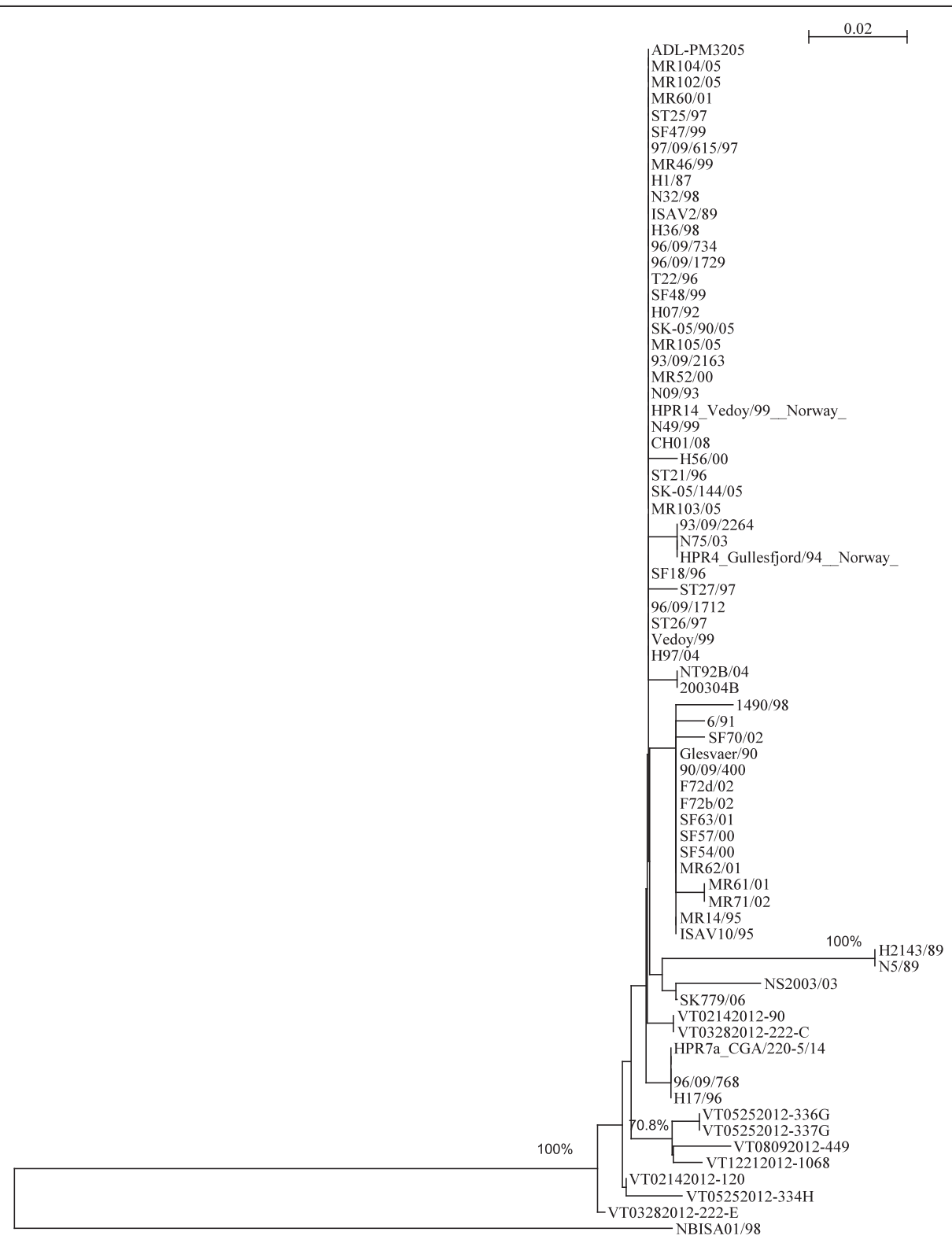

Fig. 7 Phylogenetic tree showing the genetic relationship between the 71 representative segment 6 HPR sequences aligned in Fig. 4. Sequences were aligned and the phylogenetic tree was generated by using CLUSTAL X with the default settings [58]. Phylogenetic analysis using NeighborJoining bootstrap method (1000 replicates) provided satisfactory bootstrap support (bootstrapping values are shown for branch-points with greater than $70 \%$ bootstrap support) 
pallasi) (Table 2). All fish and the sampled organs were photographed in situ. Gill and heart were sampled from the whole wild fish. Gill and remnant head kidney were sampled from the gutted, head-on farmed salmon and also the farmed salmon heads purchased from markets. The hearts were not available from these samples. All samples were placed immediately in sterile Whirl-Pak ${ }^{\oplus}$ bags (Nasco Inc., Fort Atkinson, WI) on ice with replicate samples preserved in RNALater (Ambion Inc., Foster City, CA) and shipped overnight by courier to the testing laboratory. At the laboratory, samples were immediately stored at $-80{ }^{\circ} \mathrm{C}$ until they were analyzed. The testing laboratory ran tests exclusively on the samples and did not participate in the collection of the samples or in the custody of the samples prior to receipt of the samples.

\section{Total RNA preparation}

Total RNA was isolated using a modified total RNA extraction protocol with the RNeasy ${ }^{\circ}$ mini Kit (QIAGEN). Briefly, each tissue (or pool of tissues) was weighed and macerated to a $10 \%$ suspension $\mathrm{w} / \mathrm{v}$ in phosphate buffered saline (PBS) with 10x antibiotics. The specimen supernatant was used for RNA extraction. Samples preserved in RNAlater ${ }^{\circ}$ were first washed three times with PBS and then homogenized as described above prior to total RNA extraction. Total RNA was isolated from samples using $1.25 \mathrm{ml}$ of TRIZOL Reagent (Invitrogen) and $375 \mu$ of sample volume as previously described [51]. The Viral RNA mini Kit (QIAGEN) was also utilized on selected samples following the manufacturer's recommended protocol. In all cases, the extracted RNA was eluted in 20-50 $\mu \mathrm{l}$ of nuclease-free water, and RNA yields were quantified and purity analysed using the OD260/280 ratio and a NanoDrop ND-1000 spectrophotometer (Thermo Fisher Scientific). The eluted RNA was tested immediately following quantitation, or was stored frozen at $-80{ }^{\circ} \mathrm{C}$ prior to use in RT-PCR.

\section{Real-time RT-qPCR}

RT-qPCR was run on the LightCycler 480 (Roche Applied Science), version 4.0. The crossing point $(\mathrm{Cp})$ or threshold cycle $\left(C_{\mathrm{t}}\right)$ was determined by use of the maximum-second-derivative function on the LightCycler software release 1.5.0. The Roche LightCycler ${ }^{\circ} 480$ RNA master Hydrolysis Probe kit (Roche Diagnostics) was employed for all RT-qPCR reactions according to the manufacturer's specifications. Sample RNA quality was based on RT-qPCR for elongation factor 1 alpha (ELF$1 \alpha)$ as internal control targeting either Atlantic salmon ELF-1 $\alpha$ (GenBank accession number BT072490) or Chinook salmon ELF-1 $\alpha$ (GenBank accession number FJ890356) using primers, probes, and RT-qPCR thermal cycling parameters as previously reported [52]. RNA quality varied, with the higher $C_{\mathrm{t}}$ values generally occurring in farmed salmon from markets where the interval between harvest and sampling was on the order of days, not minutes as was the case for most wild fish samples. Nonetheless, some wild fish, such as the cutthroat trout and LaP1, were caught by fishermen with unavoidable delays in processing the sampled fish. Such delays may have contributed to the higher $C_{\mathrm{t}}$ values in some of these samples. Results from tests with $C_{\mathrm{t}}$ values above 40 or at 0 were designated as negative. In addition, these samples would be considered unfit for further testing if after re-extraction and repeated RTqPCR the same results were obtained.

Detection of ISAV with the one-step real-time RTqPCR [51] was carried out using the primer-probe set developed by Snow et al. [36] targeting segment 8 and described in the OIE Aquatic Manual [38]. However, there is no defined $C_{\mathrm{t}}$ value cut off to aid interpretation of results. In this study, the cut-off $C_{\mathrm{t}}$ value for this probe was set at $\leq 34.20 \pm 1.05$ based on 10 -fold dilutions of cell culture ISAV (ADL 2007) each tested in 5 replicates and repeated 6 times for a total of 30 replicates, and denotes the mean $C_{\mathrm{t}}$ value in the highest virus dilution for which all 30 replicates were positive (Additional file 1: Table S1). The same preparations were also tested in the conventional RT-PCR methods below, allowing for a correlation of the cutoff $C_{\mathrm{t}}$ value with the conventional RT-PCR tests on cell culture virus.

\section{Conventional RT-PCR and nucleic acid sequencing}

Samples testing positive by real-time RT-qPCR were further tested using conventional one step RT-PCR targeting segments 6 and 8 to obtain PCR products for DNA sequencing. The ISAV conventional one step RT-PCR used ISAV-specific primers FA-3/RA-3 and the conditions described by Devold et al. [39] for RNA segment 8, and the following primers segment $6 \mathrm{HPR}$ primers, Fwd 5'-GCC CAG ACA TTG ACT GGA GTA G-3', and Rev 5'-AGA CAG GTT CGA TGG TGG AA-3' described by Kibenge et al. [9] for RNA segment 6, and was run in a Bio-Rad thermal cycler (Bio-Rad). Briefly, amplification was performed using $50 \mu \mathrm{l}$ reaction mixture utilizing One-step RT-PCR kit (QIAGEN) as follows: the reaction mixture contained $2 \mu \mathrm{l}$ of total RNA, $10 \mu \mathrm{l}$ of $5 \mathrm{X}$ QIAGEN OneStep RT-PCR buffer, $2 \mu$ of dNTPs, 10 units of RNAse inhibitor (Life Technologies), $0.6 \mu \mathrm{M}$ (final concentration) of each primer pair, and $2 \mu$ of QIAGEN OneStep RT-PCR enzyme mix in a final volume of $50 \mu \mathrm{l}$. The RT-PCR amplification conditions were 1 cycle at $50{ }^{\circ} \mathrm{C}$ for $30 \mathrm{~min}$, one cycle at $95^{\circ} \mathrm{C}$ for $15 \mathrm{~min}, 40$ cycles at $94{ }^{\circ} \mathrm{C}$ for $30 \mathrm{~s}, 60{ }^{\circ} \mathrm{C}$ for $60 \mathrm{~s}$ and $72{ }^{\circ} \mathrm{C}$ for $90 \mathrm{~s}$ and 1 cycle at $72{ }^{\circ} \mathrm{C}$ for $10 \mathrm{~min}$ before soaking at $4{ }^{\circ} \mathrm{C}$. Amplified products were analyzed by electrophoresis on $1 \%$ agarose gel and purified using High Pure PCR Product 
Table 3 GenBank Accession numbers used in the multiple alignments and phylogenetic analyses and of new sequences from this study

\begin{tabular}{|c|c|c|c|c|c|}
\hline Isolate or sample ID & Segment 6 & Segment 8 & Reference & $\mathrm{CH} 01 / 08$ & EU851043 \\
\hline VT02142012-120 & JQ857081 & JQ857078 & This study & $\mathrm{H} 56 / 00$ & AF364880 \\
\hline VT05252012-334H & KR998473 & KR998431 & This study & ST21/96 & AF364886 \\
\hline VT05252012-336G & KR998474 & KR998432 & This study & SK-05/144/05 & FM203274 \\
\hline VT08092012-449 & KR998475 & KR998433 & This study & MR103/05 & DQ108606 \\
\hline ISAV2/89 & DQ785246 & & & N75/03 & AY971661 \\
\hline $96 / 09 / 734$ & DQ785250 & DQ785278 & & SF18/96 & AF364869 \\
\hline $96 / 09 / 768$ & DQ785249 & DQ785277 & & ST27/97 & AF364897 \\
\hline $96 / 09 / 1729$ & DQ785251 & DQ785279 & & ST26/97 & AF364879 \\
\hline $96 / 09 / 1712$ & DQ785245 & DQ785273 & & $\mathrm{H} 97 / 04$ & DQ108604 \\
\hline $93 / 09 / 2264$ & DQ785255 & DQ785283 & & NT92B/04 & AY973188 \\
\hline $93 / 09 / 2163$ & AF427049 & DQ785281 & & 200304B & FM203244 \\
\hline HPR4_Gullesfjord/94_Norway & AF302801 & AF262384 & & $1490 / 98$ & AF391126 \\
\hline HPR14_Vedoy/99_Norway & AF302803 & AF262383 & & $6 / 91$ & AF364894 \\
\hline Glesvaer/90 & AF220607 & AF262382 & & SF70/02 & AY127880 \\
\hline $90 / 09 / 400$ & DQ785248 & DQ785276 & & $\mathrm{F} 72 \mathrm{~d} / 02$ & AY971657 \\
\hline $\mathrm{H} 2143 / 89$ & DQ785247 & DQ785275 & & $\mathrm{F} 72 \mathrm{~b} / 02$ & AY971656 \\
\hline SK779/06 & EU118820 & EU118822 & & SF63/01 & AY127879 \\
\hline NBISA01/98 & AF283996 & AF315063 & & SF57/00 & AF364890 \\
\hline VT03282012-222-C & KR998476 & & This study & SF54/00 & AF364884 \\
\hline VT03282012-222-E & KR998477 & & This study & MR62/01 & AY127878 \\
\hline VT05252012-337G & KR998478 & & This study & MR61/01 & AY127877 \\
\hline VT12212012-1068 & KR998479 & & This study & MR71/02 & AY127881 \\
\hline ADL-PM3205 & HQ011267 & & & MR14/95 & AF364873 \\
\hline MR104/05 & DQ108607 & & & ISAV10/95 & DQ78525 \\
\hline MR102/05 & DQ108605 & & & N5/89 & AY127882 \\
\hline MR60/01 & AY127876 & & & NS2003/03 & AY973182 \\
\hline ST25/97 & AF364885 & & & HPR7a_CGA/220-5/14 & KJ944288 \\
\hline SF47/99 & AF364888 & & & $96 / 09 / 768$ & DQ785249 \\
\hline 97/09/615/97 & DQ785252 & & & $\mathrm{H} 17 / 96$ & AF364891 \\
\hline MR46/99 & AF364896 & & & VT03202012-194 & \\
\hline $\mathrm{HI} / 87$ & AF364893 & & & VT03202012-195 & \\
\hline N32/98 & AF364883 & & & VT03202012-196 & \\
\hline $\mathrm{H} 36 / 98$ & AF302799 & & & VT03202012-199 & \\
\hline T22/96 & AF364889 & & & VT03202012-200 & \\
\hline SF48/99 & AF364878 & & & VT03202012-202 & \\
\hline H07/92 & AF364898 & & & VT03202012-204A & \\
\hline SK-05/90/05 & FM203287 & & & VT03202012-215 & \\
\hline MR105/05 & DQ108608 & & & VT03202012-216 & \\
\hline MR52/00 & AF364892 & & & VT03202012-217 & \\
\hline N09/93 & AF364895 & & & VT03202012-218 & \\
\hline N49/99 & AF364876 & & & VT03202012-219 & \\
\hline
\end{tabular}

Table 3 GenBank Accession numbers used in the multiple alignments and phylogenetic analyses and of new sequences from this study (Continued)

\begin{tabular}{|c|c|c|c|}
\hline CH01/08 & EU851043 & & \\
\hline H56/00 & AF364880 & & \\
\hline ST21/96 & AF364886 & & \\
\hline SK-05/144/05 & FM203274 & & \\
\hline MR103/05 & DQ108606 & & \\
\hline N75/03 & AY971661 & & \\
\hline SF18/96 & AF364869 & & \\
\hline ST27/97 & AF364897 & & \\
\hline ST26/97 & AF364879 & & \\
\hline H97/04 & DQ108604 & & \\
\hline NT92B/04 & AY973188 & & \\
\hline $200304 B$ & FM203244 & & \\
\hline 1490/98 & AF391126 & & \\
\hline $6 / 91$ & AF364894 & & \\
\hline SF70/02 & AY127880 & & \\
\hline $\mathrm{F} 72 \mathrm{~d} / 02$ & AY971657 & & \\
\hline $\mathrm{F} 72 \mathrm{~b} / 02$ & AY971656 & & \\
\hline SF63/01 & AY127879 & & \\
\hline SF57/00 & AF364890 & & \\
\hline SF54/00 & AF364884 & & \\
\hline MR62/01 & AY127878 & & \\
\hline MR61/01 & AY127877 & & \\
\hline MR71/02 & AY127881 & & \\
\hline MR14/95 & AF364873 & & \\
\hline ISAV10/95 & DQ785254 & & \\
\hline N5/89 & AY127882 & & \\
\hline NS2003/03 & AY973182 & & \\
\hline HPR7a_CGA/220-5/14 & KJ944288 & & \\
\hline 96/09/768 & DQ785249 & & \\
\hline$H 17 / 96$ & AF364891 & & \\
\hline VT03202012-194 & & KR998434 & This study \\
\hline VT03202012-195 & & KR998435 & This study \\
\hline VT03202012-196 & & KR998436 & This study \\
\hline VT03202012-199 & & KR998437 & This study \\
\hline VT03202012-200 & & KR998438 & This study \\
\hline VT03202012-202 & & KR998439 & This study \\
\hline VT03202012-204A & & KR998440 & This study \\
\hline VT03202012-215 & & KR998441 & This study \\
\hline VT03202012-216 & & KR998442 & This study \\
\hline VT03202012-217 & & KR998443 & This study \\
\hline VT03202012-218 & & KR998444 & This study \\
\hline VT03202012-219 & & KR998445 & This study \\
\hline
\end{tabular}


Table 3 GenBank Accession numbers used in the multiple alignments and phylogenetic analyses and of new sequences from this study (Continued)

\begin{tabular}{|c|c|c|}
\hline VT05012012-308 & KR998424 & This study \\
\hline VT05252012-336H & KR998425 & This study \\
\hline VT05252012-338G & KR998446 & This study \\
\hline VT06042012-341G & KR998447 & This study \\
\hline VT06042012-341H & KR998448 & This study \\
\hline VT06042012-343H & KR998449 & This study \\
\hline VT06042012-345H & KR998450 & This study \\
\hline VT08092012-402 & KR998451 & This study \\
\hline VT08092012-406 & KR998452 & This study \\
\hline VT08092012-419 & KR998453 & This study \\
\hline VT08092012-420 & KR998454 & This study \\
\hline VT08092012-421 & KR998455 & This study \\
\hline VT08092012-423 & KR998456 & This study \\
\hline VT08092012-425 & KR998457 & This study \\
\hline VT08092012-431 & KR998426 & This study \\
\hline VT08092012-433 & KR998427 & This study \\
\hline VT08092012-434 & KR998458 & This study \\
\hline VT08092012-446 & KR998428 & This study \\
\hline VT08092012-447 & KR998459 & This study \\
\hline VT08092012-450 & KR998460 & This study \\
\hline VT08092012-451 & KR998461 & This study \\
\hline VT08092012-465 & KR998462 & This study \\
\hline VT08092012-466 & KR998463 & This study \\
\hline VT08092012-468 & KR998464 & This study \\
\hline VT08092012-476 & KR998465 & This study \\
\hline VT08092012-478 & KR998466 & This study \\
\hline VT08092012-481 & KR998467 & This study \\
\hline VT06202012-379 & KR998468 & This study \\
\hline VT06202012-380 & KR998469 & This study \\
\hline VT06202012-387 & KR998470 & This study \\
\hline VT06202012-388 & KR998429 & This study \\
\hline VT06202012-391 & KR998471 & This study \\
\hline VT01222013-03 & KR998430 & This study \\
\hline VT06062013-60 & KR998472 & This study \\
\hline Vir22_96/09/724 & DQ785286 & \\
\hline 97/09/393 & DQ785284 & \\
\hline 97/09/615 & DQ785280 & \\
\hline $94 / 09 / 579$ & DQ785285 & \\
\hline SF83/04 & AY744395 & \\
\hline Svolvaer/96 & AF262381 & \\
\hline Bremnes/98 & AF262385 & \\
\hline Brekke/98 & AF262380 & \\
\hline
\end{tabular}

Table 3 GenBank Accession numbers used in the multiple alignments and phylogenetic analyses and of new sequences from this study (Continued)

\begin{tabular}{ll}
\hline Eikelandsosen/89 & AF262386 \\
$810 / 9 / 99$ & DQ022085 \\
95 & DQ785282 \\
901 & GU830910 \\
752 & GU830902 \\
$390 / 98$ & DQ003602 \\
$485 / 9 / 97$ & DQ003605 \\
U5575-1 & DQ003603 \\
$04-085-1$ & DQ058660 \\
$01-0973-3$ & DQ003607 \\
$02-1179-4$ & DQ003601 \\
$00-0593-1$ & DQ003606 \\
$02-0775-14$ & DQ003604 \\
$98-049-1$ & DQ003600 \\
RPC/NB-280-2 & AF312317 \\
AF109304 & AF109304 \\
RPC/NB-877 & AF312316 \\
7833-1 & AF312315 \\
Fundy/97 & AF262389 \\
AF404340 & AF404340 \\
NB458 & AY151798 \\
\hline
\end{tabular}

Purification Kit (Roche). The PCR products were cloned into the pCRII vector using a TOPO TA cloning kit (Invitrogen) in preparation for nucleotide sequencing, although in some cases the RT-PCR products were sequenced directly without cloning. Plasmid DNA for sequencing was prepared as per Kibenge et al. [53], and DNA sequencing as per Kibenge et al. [10] by ACGT Corporation (Toronto, Ontario, Canada). Sequence analysis used the BLAST programs [54] against the latest release at GenBank [55], the Sequence Manipulation suite version 2 [56], and the FASTA program package for microcomputers [57]. Sequences are available through GenBank and their accession numbers are listed in Table 3.

\section{Phylogenetic analyses}

Sequences were aligned and phylogenetic trees were generated using CLUSTAL X with the default settings [58]. Alignment regions containing gaps were excluded from the analysis. The results were analyzed by using the bootstrap method (1000 replicates) to provide confidence levels for the tree topology. We then used different outgroup sequences to determine and verify the root of each tree. 


\section{Virus isolation}

Primary virus isolation was attempted on some of the RT-PCR "non-negative" samples using Salmon head kidney (SHK-1 and ASK-2) cell line monolayers. SHK-1 [59] and ASK-2 cells [39] were grown as previously described [12]. Homogenized tissues were inoculated on monolayers of SHK-1 and/or ASK-2 cell lines following standard protocols in the OIE Aquatic Manual [38]. Briefly, each tissue was weighed and macerated to a $10 \%$ homogenate w/v in PBS with $10 x$ antibiotics. The homogenates were centrifuged at $205.3 \mathrm{~g}$ for $15 \mathrm{~min}$ at $4{ }^{\circ} \mathrm{C}$. The supernatants were individually filtered using $0.45 \mu \mathrm{M}$ syringe filters to remove any bacteria prior to use in virus isolation attempts. $24 \mathrm{hr}$-old cell monolayers in tissue culture flasks free of medium were inoculated with the sample supernatant diluted 1:10 in serum-free medium, and incubated for $2 \mathrm{hr}$ at room temperature to allow for virus adsorption. Maintenance medium was then added and the inoculated cells were then incubated at $16{ }^{\circ} \mathrm{C}$ and infection was allowed to proceed with daily monitoring using an inverted light microscope until the CPE was evident or 21 days and the flasks were frozen at $-80{ }^{\circ} \mathrm{C}$. Virus isolation was monitored by RT-PCR on the cell lysates since virus replication may occur without development of apparent CPE [60]. CPE negative and RT-PCR negative cultures were passaged on fresh cell monolayers. A sample was considered negative if no CPE or positive RT-PCR was observed after three blind passages.

\section{Ethics}

The in vitro work was approved by the UPEI Biosafety Committee.

\section{Additional files}

Additional file 1: Correlation of mean $\mathrm{Ct}$ value with conventional RT-PCR with ISAV segment 8 and HPR primers on cell culture virus. Table showing Correlation of mean $C_{\mathrm{t}}$ value with conventional RT-PCR with ISAV segment 8 and HPR primers on cell culture virus. (DOC $33 \mathrm{~kb}$ )

Additional file 2: Fish tissue samples testing "non-negative" for infectious salmon anaemia virus (ISAV) from 2012-2013 ${ }^{1}$. Table listing the ISAV segment 8 tests done in replicates, which were in some cases repeated. Values in this column represent how many replicates produced a $C_{t}$ value, or the averaged result of tests. (DOC $117 \mathrm{~kb}$ )

\section{Competing interest}

The authors declare they have no competing financial interest in relation to this report.

\section{Authors' contributions}

MJTK isolated total RNA from tissue samples, performed the RT-qPCR for ELF-1a and ISAV, conventional RT-PCR for ISAV, cloned PCR products for sequencing, and helped to write the manuscript. TI performed conventional RT-PCR for ISAV and cloned PCR products for sequencing and helped to write the manuscript. YW performed all the multiple alignments and phylogenetic analyses and helped to write the manuscript. AM provided the Canadian samples for diagnostic testing and helped to write the manuscript. RR provided the Canadian samples for diagnostic testing, performed the statistical analysis of the ELF-1a $C_{t}$ values and helped to write the manuscript. FSBK performed the virus isolation attempts, coordinated all viral testing and DNA sequence analysis and helped to write the manuscript. All authors read and approved the final manuscript.

\section{Acknowledgements}

This work was supported by the Virology Research Laboratory at the Atlantic Veterinary College, University of Prince Edward Island, Charlottetown, PE, Canada, and a Natural Sciences and Engineering Research Council (NSERC) of Canada Discovery Grant to F.S.B.K. Van City, Rudy North, James Corbett, Patagonia, Tony and Kim Allard, Dick and Val Bradshaw, Vancouver Foundation, the Tula Foundation, Elizabeth Borak, Wheeler Family Foundation, Yvon Chouinard, Eden Conservation Trust, Sarah Haney, Tides Foundation, Jaymac Foundation, an NSERC grant to R.R. and many smaller donors. Thank you to the First Nations who assisted and allowed us to sample their fish - Boston Bar, Gitanyow Fisheries, Gitxsan Fisheries Authorities, Heiltsuk, Kwikwasut'inuxw Haxwa'mis, Lake Babine Nation Fisheries, Lake Cowichan, Mowachaht/Muchalaht, N'Quatqua, Nicola, Seton Lake, Shuswap, Skeena First Nations, Snuneymuxw, Splatsin, St'at'imc, Stellaquo, Stó:lō , Takla Lake, Xeni Gwet'in, Office of the Wet'suwet'en Fisheries and Wuikinuxv First Nations. We also thank Rob, Nola, Krystal and Amber-Bachen, Sandy Bodrug, Farlyn and Tavish Campbell, Tamara and Roy Campbell, Brad Crowther, Roger Dunlop, Jody Eriksson, Randy Ericksen, Dave and Nicole Gerbrandt, Nicole, Donna and Bill Mackay, Jennifer Parkhouse, Stan Proboszcz, Anissa Reed, Dave Rolston, Louise Routledge, Steve Sharron, Tsylos Park Lodge, Ted and Duane Walkus, Monica Woods, and Sabra Woodworth.

\section{Author details}

'Department of Pathology and Microbiology, Atlantic Veterinary College, University of Prince Edward Island, 550 University Ave., Charlottetown, P.E.I. C1A 4P3, Canada. ${ }^{2}$ Department of Computer Science, University of Prince Edward Island, 550 University Ave., Charlottetown, P.E.I. C1A 4P3, Canada. ${ }^{3}$ Raincoast Research Society, Box 399, 390 1st Street, Sointula, BC VON 3E0, Canada. ${ }^{4}$ Department of Statistics and Actuarial Science, Simon Fraser University, 8888 University Drive, Burnaby, B.C. V5A 156, Canada. ${ }^{5}$ Current address: Diagnostic Services Unit, Atlantic Veterinary College, University of Prince Edward Island, 550 University Ave., Charlottetown, P.E.I. C1A 4P3, Canada.

Received: 27 October 2015 Accepted: 28 December 2015

Published online: 06 January 2016

\section{References}

1. McCauley J, Hongo S, Kaverin N, Kochs G, Lamb R, Matrosovich M, et al. Family Orthomyxoviridae. In: King AMQ, Adams MJ, Carstens EB, Lefkowitz EJ, editors. Virus Taxonomy: Ninth Report of the International Committee on Taxonomy of Viruses. San Diego, CA: Academic; 2011. p. 749-61.

2. Adams S, Xing Z, Li J, Kristelle M, Perez D, Reed K, et al. The effect of avian influenza virus NS1 allele on virus replication and innate gene expression in avian cells. Mol Immunol. 2013;56:358-68.

3. Hause B, Collin E, Liu R, Huang B, Sheng Z, Lu W, et al. Characterization of a novel influenza virus strain in cattle and swine: proposal for a new genus in the Orthomyxoviridae family. MBio. 2014;5:1-14.

4. Anonymous. Fish Diseases; Emerging viruses. 2013 http://wfrc.usgs.gov/ fieldstations/hq/emerging.html (Consulted on Oct 1, 2015).

5. Granzow H, Fichtner D, Schütze $H$, Lenk M, Dresenkamp B, Nieper $H$, et al. Isolation and partial characterization of a novel virus from different carp species suffering gill necrosis - ultrastructure and morphogenesis. J Fish Dis. 2014;37:559-69.

6. McCann R Viral survey of fathead minnows, golden shiners, and white suckers from baitfish dealers in Wisconsin. Master's Degree Thesis, 2012 College of Science and Health, University of Wisconsin, La Crosse, USA.

7. Blake S, Bouchard D, Keleher W, Opitz M, Nicholson B. Genomic relationships of the North American isolate of infectious salmon anemia virus (ISAV) to the Norwegian strain of ISAV. Dis Aquat Organ. 1999;35:139-44.

8. Kibenge FSB, Kibenge MJ, McKenna PK, Stothard P, Marshall R, Cusack RR, et al. Antigenic variation among isolates of infectious salmon anaemia virus (ISAV) correlates with genetic variation of the viral haemagglutinin gene. J Gen Virol. 2001;82:2869-79. 
9. Kibenge FSB, Godoy MG, Wang Y, Kibenge MJT, Gherardelli V, Mansilla S, et al. Infectious salmon anaemia virus (ISAV) isolated from the ISA disease outbreaks in Chile diverged from ISAV isolates from Norway around 1996 and was disseminated around 2005, based on surface glycoprotein gene sequences. Virol J. 2009;6:88.

10. Kibenge FSB, Kibenge MJT, Wang Y, Qian B, Hariharan S, McGeachy S. Mapping of putative virulence motifs on infectious salmon anaemia virus surface glycoprotein genes. J Gen Virol. 2007;88:3100-11.

11. Nylund A, Plarre H, Karlsen M, Fridell F, Ottem KF, Bratland A, et al. Transmission of infectious salmon anaemia virus (ISAV) in farmed populations of Atlantic salmon (Salmo salar). Arch Virol. 2007;152:151-79.

12. Kibenge FSB, Kibenge MJT, Groman D, McGeachy S. In vivo correlates of infectious salmon anaemia virus pathogenesis in fish. J Gen Virol. 2006;87:2645-52.

13. Christiansen D, Østergaard PS, Snow MI, Dales OB, Falk K. A low-pathogenic variant of infectious salmon anemia virus (ISAV1 - HPRO) is highly prevalent and causes a non-clinical transient infection in farmed Atlantic salmon (Salmo salar L.) in the Faroe Islands. J Gen Virol. 2011;92:909-18.

14. Plarre $H$, Nylund A, Karlsen M, Brevik $\varnothing$, Sæther PA, Vike S. Evolution of infectious salmon anaemia virus (ISA virus). Arch Virol. 2012;157:2309-26

15. González RR, Ruiz P, Llanos-Rivera A, Cruzat F, Silva J, Astuya A, et al. ISA virus outside the cage: Ichthyofauna and other possible reservoirs to be considered for marine biosafety management in the far-southern ecosystems of Chile. Aquaculture. 2011;318:37-42.

16. Marshall SH, Ramírez R, Labra A, Carmona M, Muñoz C. Bona fide evidence for natural vertical transmission of infectious salmon anemia virus in freshwater brood stocks of farmed Atlantic salmon (Salmo salar) in Southern Chile. J Virol. 2014;88:6012-8.

17. CFIA: ARCHIVED - 2012 - 2013 Status Update on the Surveillance of Wild and Enhanced Anadromous Salmonids in British Columbia. 2014 http:// www.inspection.gc.ca/animals/aquatic-animals/diseases/reportable/isa/wildanadromous-salmonids/eng/1410057185143/1410057186002.

18. Sepúlveda D, Cárdenas C, Carmona M, Marshall SH. Novel strategy to evaluate infectious salmon anemia virus variants by high resolution melting. PLoS One. 2012;7:e37265

19. Abdelwhab EM, Erfan AM, Grund C, Ziller M, Arafa A-S, Beer M, et al. Simultaneous detection and differentiation by multiplex real time RT-PCR of highly pathogenic avian influenza subtype H5N1 classic (clade 2.2.1 proper) and escape mutant (clade 2.2.1 variant) lineages in Egypt. Virol J. 2010;7:1-8.

20. Klungthong C, Chinnawirotpisan P, Hussem K, Phonpakobsin T, Manasatienkij W, Ajariyakhajorn C, et al. The impact of primer and probetemplate mismatches on the sensitivity of pandemic influenza A/H1N1/ 2009 virus detection by real-time RT-PCR. J Clin Virol. 2010;48:91-5.

21. Kumar S, Henrickson KJ. Update on influenza diagnostics: lessons from the novel H1N1 influenza A pandemic. Clin Microbiol Rev. 2012;25:344-61.

22. Caraguel C, Stryhn H, Gagné N, Dohoo I, Hammell L. A modeling approach to predict the variation of repeatability and reproducibility of a RT-PCR assay for infectious salmon anaemia virus across infection prevalences and infection stages. Prev Vet Med. 2012;103:63-73.

23. Nérette P, Dohoo I, Hammell L, Gagné N, Barbash P, Maclean S. Estimation of the repeatability and reproducibility of three diagnostic tests for infectious salmon anaemia virus. J Fish Dis. 2005:28:101-10.

24. CFIA: Canada completes infectious salmon anaemia testing: No confirmed cases in BC salmon - December 02, 2011. http://www.inspection.gc.ca/ english/corpaffr/newcom/2011/20111202e.shtml.

25. DFO: Accepted Testing Methods for ISAV - November 2011. http://www. dfo-mpo.gc.ca/media/back-fiche/2011/20111108-eng.htm.

26. Kibenge FSB, Munir K, Kibenge MJT, Joseph T, Moneke E. Infectious salmon anaemia virus: causative agent, pathogenesis and immunity. Anim Health Res Rev. 2004:5:65-78.

27. Rimstad E, Mjaaland S. Infectious salmon anaemia virus - an orthomyxovirus causing an emerging infection in Atlantic salmon. Apmis. 2002;110:273-82.

28. Mjaaland S, Hungnes O, Teig A, Dannevig BH, Thorud K, Rimstad E. Polymorphism in the Infectious Salmon Anemia Virus Hemagglutinin Gene: Importance and Possible Implications for Evolution and Ecology of Infectious Salmon Anemia Disease. Virology. 2002;304:379-91.

29. Lyngstad TM, Kristoffersen AB, Hjortaas MJ, Devold M, Aspehaug V, Larssen $\mathrm{RB}$, et al. Low virulent infectious salmon anaemia virus (ISAV-HPRO) is prevalent and geographically structured in Norwegian salmon farming. Dis Aquat Organ. 2012;101:197-206.
30. Gagné N, Ritchie RJ. Development of a strand-specific RT-PCR assay for ISAV. Can Tech Rep Fish Aquat Sci. 2006;2675:1-32.

31. Plarre $H$, Devold M, Snow M, Nylund A. Prevalence of infectious salmon anaemia virus (ISAV) in wild salmonids in Western Norway. Dis Aquat Organ. 2005;66:71-9.

32. Leland DS, Ginocchio CC. Role of cell culture for virus detection in the age of technology. Clin Microbiol Rev. 2007;20:49-78.

33. Knüsel R, Bergmann SM, Casey J, Segner H, Wahli T. Virus isolation vs RT-PCR: which method is more successful in detecting VHSV and IHNV in fish tissue sampled under field conditions? J Fish Dis. 2007:30:559-68.

34. Bergh $\mathrm{O}$. The dual myths of the healthy wild fish and the unhealthy farmed fish. Dis Aquat Org. 2007:75:159-64.

35. Garibyan L, Avashia N. Polymerase Chain Reaction. J Invest Dermatol. 2013;133:e6.

36. Snow M, McKay P, McBeath AJ, Black J, Doig F, Kerr R, et al. Development, application and validation of a Taqman ${ }^{\oplus}$ real-time RT-PCR assay for the detection of infectious salmon anaemia virus (ISAV) in Atlantic salmon (Salmo salar). Dev Biol. 2006;126:133-45.

37. Kibenge FSB, Kibenge MJT, Masaoud E. Infectious Salmon Anaemia Virus (ISAV) Ringtest: Validation of the ISAV Diagnostic Process using Virus-spiked Fish Tissues and ISAV TaqMan ${ }^{\oplus}$ Real-time RT-PCR. J Aquac Res and Devel. 2011;2:1-8.

38. OIE: Manual of Diagnostic Tests for Aquatic Animals 2015, http://www.oie. int/international-standard-setting/aquatic-manual/access-online/

39. Devold M, Krossøy B, Aspehaug $V$, Nylund A. Use of RT-PCR for diagnosis of infectious salmon anaemia virus (ISAV) I carrier sea trout Salmo trutta after experimental infection. Dis Aquat Org. 2000;40:9-18.

40. Casselman A: More salmon shenanigans in British Columbia. Nature News Blog, December 02, 2011 http://blogs.nature.com/news/2011/12/more_ salmon_shenanigans_in_bri.html.

41. Amos KH, Gustafson L, Warg J, Whaley J, Purcell M, Rolland J, et al. U.S. Response to a Report of Infectious Salmon Anemia Virus in Western North America. Fisheries. 2014;39:501-6.

42. Cohen Commission: Exhibits1549, 2040, 2042, 2043, 2044, 2045, 2051, 2052, 2053, 2060 https://web.archive.org/web/20131114212437/http://www. cohencommission.ca/en/Exhibits.php

43. Bates D, Mächler M, Bolker BM, Walker, SC: Fitting Linear Mixed-Effects Models using Ime4. https://cran.r-project.org/web/packages//me4/vignettes/ Imer.pdf.

44. EFSA: European Food Safety Authority (EFSA) Panel on Animal Health and Welfare (AHAW): Scientific opinion on infectious salmon anaemia. EFSA Journal 2012, 10:2971. http://www.efsa.europa.eu/en/efsajournal/ pub/2971.htm.

45. Nylund A, Devold M, Plarre H, Isdal E, Aarseth M. Emergence and maintenance of infectious salmon anaemia virus (ISAV) in Europe: a new hypothesis. Dis Aquat Org. 2003;56:11-24.

46. Lyngstad TM, Jansen PA, Sindre H, Jonassen CM, Hjortaas MJ, Johnsen S, et al. Epidemiological investigation of infectious salmon anaemia (ISA) outbreaks in Norway 2003-2005. Prev Vet Med. 2008;84:213-27.

47. Rodger HD, Turnbull T, Muir F, Millar S, Richards RH. Infectious salmon anaemia (ISA) in the United Kingdom. B Eur Assoc Fish Pathol. 1998;18:115-6.

48. Cottet L, Cortez-San Martin M, Tello M, Olivares E, Rivas-Aravena A, Vallejos

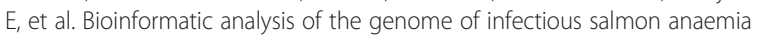
virus associated with outbreaks with high mortality in Chile. J Virol. 2010;84:11916-28

49. Cunningham CO, Gregory A, Black J, Simpson I, Raynard RS. A novel variant of infectious salmon anaemia virus (ISAV) haemagglutinin gene suggests mechanisms for virus diversity. Bull Eur Ass Fish Pathol. 2002;22:366-74.

50. Castro-Nallar E, Martín MC-S, Mascayano C, Molina C, Crandall KA. Molecular Phylodynamics and protein modeling of infectious salmon anaemia virus (ISAV). BMC Evol Biol. 2011;11:349.

51. Workenhe ST, Kibenge MJT, Iwamoto T, Kibenge FSB. Absolute quantitation of infectious salmon anaemia virus using different real-time reverse transcription PCR chemistries. J Virol Methods. 2008;154:128-34.

52. Kibenge MJT, Iwamoto T, Wang Y, Morton A, Godoy MG, Kibenge FSB. Whole-genome analysis of piscine reovirus (PRV) shows PRV represents a new genus in family Reoviridae and its genome segment $\mathrm{S1}$ sequences group it into two separate sub-genotypes. Virol J. 2013;10:230.

53. Kibenge FSB, Dybing JK, McKenna KP. Rapid procedure for large-scale isolation of plasmid DNA. Biotechniques. 1991;11:65-7. 
54. Altschul SF, Gish W, Miller W, Myers EW, Lipman DJ. Basic local alignment search tool. J Mol Biol. 1990;215:403-10.

55. GenBank Database: http://www.ncbi.nlm.nih.gov/Genbank

56. Stothard P. The Sequence Manipulation Suite: JavaScript Programs for Analyzing and Formatting Protein and DNA Sequences. Biotechniques. 2000;28:1102-4. http://www.ualberta.ca/ stothard/javascript/index.html.

57. Pearson WR, Lipman DJ. Improved tools for biological sequence comparison. Proc Natl Acad Sci U S A. 1998;85:2444-8.

58. Thompson JD, Gibson TJ, Plewniak F, Jeanmougin F, Higgins DG. The CLUSTAL X windows interface: flexible strategies for multiple sequence alignment aided by quality analysis tools. Nucl Acids Res. 1997;25:4876-82.

59. Dannevig BH, Falk K, Namork E. Isolation of the causal virus of infectious salmon anemia (ISA) in a long-term cell line from Atlantic head kidney. J Gen Virol. 1995;76:1353-9.

60. Munir K, Kibenge FSB. Detection of infectious salmon anaemia virus by real-time RT-PCR. J Virol Methods. 2004;117:37-47.

61. Raynard RS, Murray AG, Gregory A. Infectious salmon anemia virus in wild fish from Scotland. Dis Aquat Organ. 2001;46:93-100.

62. Olivier G. Disease interactions between wild and cultured fish - Perspectives from the American Northeast (Atlantic Provinces). Bull Eur Assoc Fish Pathol. 2002;22:103-9.

63. Mullins JE, Groman D, Wadowska D. Infectious salmon anaemia in salt water Atlantic salmon (Salmo salar L.) in New Brunswick, Canada. Bull Eur Assoc Fish Pathol. 1998:18:110-4.

64. Raynard RS, Murray AG, Gregory A. Infectious salmon anaemia virus in wild fish from Scotland. Dis Aquat Org. 2001:46:93-100.

65. MacLean SA, Brown RW: ISA outbreaks and disease testing of Atlantic salmon in the United States and the West Greenland fishery. Work. Pap. 2002/20. Copenhagen: International Council for the Exploration of the Sea North Atlantic Salmon Working Group. 3 p.

66. MacLean SA, Bouchard DA, Ellis SK. Survey of non-salmonid marine fishes for detection of infectious salmon anaemia virus and other salmonid pathogens. In: Miller O, Cipriano RC, editors. International response to infectious salmon anemia: prevention, control, and eradication: Symposium Proceedings. 3-4 September 2002, New Orleans, LA. Tech Bull. Washington, DC: US Dept Agriculture; 2003. p. 135-44.

67. Bouchard DA, Brockway K, Giray C, Keleher W, Merrill PL. First report of infectious salmon anemia (ISA) in the United States. Bull Eur Assoc Fish Pathol. 2001;21:86-8.

68. Thorud KE, Djupvik HO. Infectious salmon anaemia in Atlantic salmon (Salmo salar L). Bull Eur Assoc Fish Pathol. 1988;8:109-11.

69. Cipriano RC. Antibody against infectious salmon anaemia virus among feral Atlantic salmon (Salmo salar). ICES J Mar Sci. 2009;66:865-70.

70. Skall HF: Detection of HPRO in Denmark and criteria for diagnosis of ISA. In Report on the 15th Annual Meeting of the National Reference Laboratories for Fish Diseases. Copenhagen, Denmark. 2011:48-49.

71. Godoy MG, Aedo A, Kibenge MJT, Groman DB, Yason CV, Grothusen H, et al. First detection, isolation and molecular characterization of infectious salmon anaemia virus associated with clinical disease in farmed Atlantic salmon (Salmo salar) in Chile. BMC Vet Res. 2008:4:1-13.

72. Anonymous: ISA hits the Faroes. Fish Farming Int 2000, 47.

\section{Submit your next manuscript to BioMed Central and we will help you at every step:}

- We accept pre-submission inquiries

- Our selector tool helps you to find the most relevant journal

- We provide round the clock customer support

- Convenient online submission

- Thorough peer review

- Inclusion in PubMed and all major indexing services

- Maximum visibility for your research

Submit your manuscript at www.biomedcentral.com/submit

) Biomed Central 